\title{
Performance of Anammox Processes for Wastewater Treatment: A Critical Review on Effects of Operational Conditions and Environmental Stresses
}

\author{
Sunja Cho ${ }^{1}$, Cicilia Kambey ${ }^{2}$ and Van Khanh Nguyen ${ }^{1, *(1)}$ \\ 1 Department of Microbiology, Pusan National University, Busan 46241, Korea; chosj@pusan.ac.kr \\ 2 Division of Earth and Environmental System, Pusan National University, Busan 46241, Korea; \\ cicilia_kambey@yahoo.com \\ * Correspondence: khanhnv88@pusan.ac.kr; Tel.: +82-51-510-2271
}

Received: 31 October 2019; Accepted: 16 December 2019; Published: 19 December 2019

check for updates

\begin{abstract}
The anaerobic ammonium oxidation (anammox) process is well-known as a low-energy consuming and eco-friendly technology for treating nitrogen-rich wastewater. Although the anammox reaction was widely investigated in terms of its application in many wastewater treatment processes, practical anammox application at the pilot and industrial scales is limited because nitrogen removal efficiency and anammox activity are dependent on many operational factors such as temperature, $\mathrm{pH}$, dissolved oxygen concentration, nitrogen loading, and organic matter content. In practical application, anammox bacteria are possibly vulnerable to non-essential compounds such as sulfides, toxic metal elements, alcohols, phenols, and antibiotics that are potential inhibitors owing to the complexity of the wastewater stream. This review systematically summarizes up-to-date studies on the effect of various operational factors on nitrogen removal performance along with reactor type, mode of operation (batch or continuous), and cultured anammox bacterial species. The effect of potential anammox inhibition factors such as high nitrite concentration, high salinity, sulfides, toxic metal elements, and toxic organic compounds is listed with a thorough interpretation of the synergistic and antagonistic toxicity of these inhibitors. Finally, the strategy for optimization of anammox processes for wastewater treatment is suggested, and the importance of future studies on anammox applications is indicated.
\end{abstract}

Keywords: anammox; optimization; operational factors; toxic compounds; inhibition

\section{Introduction}

Implementation of anaerobic ammonium oxidation (anammox) in many water technologies has gained increasing attention since it was first discovered in the 1980s [1]. The application of the anammox process in wastewater systems has resulted in higher rates of nitrogen removal and lower energy requirements than those for conventional nitrogen removal [2-5]. Because of these advantages, anammox bacteria were selected for use in wastewater management owing to their high salt tolerance, wide temperature tolerance, and high capability for the removal of organic waste. Moreover, the anammox process is known to be responsible for $50 \%$ of nitrogen turnover in marine environments at various temperature and salinity conditions $[6,7]$.

Anammox bacteria belonging to Planctomycetes contain a membrane-bound organelle that can convert ammonium and nitrite to dinitrogen gas using a process involving the production of the toxic and extremely energy-rich hydrazine intermediate [8]. During wastewater treatment, high organic matter in the wastewater is degraded to carbon dioxide by microorganisms through an aeration system known as the activated sludge process. This process is energy intensive, particularly for 
the aeration systems. Conventional denitrification often requires additional organic matter for the reduction of nitrate to dinitrogen gas [8]. In combination with the anammox process in wastewater treatment, the remaining waste containing high ammonium will continue to be degraded by anammox; the problem of sludge in the treatment process can thus be mitigated [9-11]. The water treatment process has been recognized to be a two-step process, comprising a sidestream and a mainstream process, which are divided based on influent sources and bacterial involvement. The introduction of the mainstream process enables the decoupling of carbon and nitrogen removal and maximizes energy recovery through a carbon-concentrating pre-treatment process that channels more carbon to an anaerobic digester (or an up-flow anaerobic sludge blanket (UASB) reactor) for biogas generation [12]. There are two consecutive steps in the mainstream process. First, the primary conversion of ammonium to nitrite facilitated by ammonium-oxidizing bacteria (AOB), which is known as partial nitritation (PN). In the second step, the remaining ammonium reacts with nitrite to produce dinitrogen gas supported by anaerobic oxidizing bacteria named anammox (A). The partial nitritation and anammox (PN/A) process has been studied and applied at numerous scales of wastewater treatment to improve energy utilization efficiency [12-14]. The PN/A process provides environmental advantages over conventional nitrogen removal such as $60 \%$ reduction in oxygen demand, elimination of $95 \%$ of the biodegradable carbon, and $80 \%$ reduction in sludge, which are the main purposes of modern wastewater treatment [2,15-18].

Unlike that of other bacteria, the growth rate of anammox bacteria is quite slow, with the exponential phase being 10-22 days [19] or within 10-12 days when cultured at $35^{\circ} \mathrm{C}$; therefore, its application is limited to the operation of continuous wastewater treatment processes containing high concentrations of ammonium or other organic matter. Environmental factors play an important role in triggering high bacterial growth rates. High nitrogen removal performance can be enhanced by optimizing the operating conditions and limiting environmental stresses. However, it is difficult to create such conditions in an operating bioreactor system. An investigation of growth characteristics of anammox bacteria and their response to various environmental perturbations can help reveal their capacity to adapt in these limiting conditions.

There are many challenges in maintaining the operational condition of anammox systems, either in the mainstream or the sidestream, to achieve a stable high nitrogen removal rate. In the mainstream, a longer start-up period, lower nitrogen concentrations, and inconsistency in loading rate become the most important challenges that may affect the inflexibility and instability of effluent nitrogen concentrations $[2,20]$. The difficulties in controlling organic solids in the influent and microspatial aeration have been documented as principal problems [14]. In addition, inhibition by exogenous compounds, such sulfides, phenols, alcohols, antibiotics, or toxic metals in substrate media, is an important factor to be considered [21-24]. Although nitrite is a substrate of the anammox reaction, at a concentration higher than $100 \mathrm{mg} / \mathrm{L}$, it becomes toxic to anammox growth [25-28]. The competition for nutrient and oxygen among bacteria can inhibit the capacity for growth and anammox activity, which should be taken into account $[12,13,29,30]$. Nevertheless, environmental parameters such as temperature, oxygen concentration, organic carbon content, nitrogen concentration, and $\mathrm{pH}$ are important factors influencing the mainstream process, while the sidestream process is mainly affected by high organic carbon content in the system. The influence of environmental factors in each bioreactor, whether in the operational mainstream or in sidestream processes, was previously investigated at different scales of operation including in industrial and municipal wastewater treatment units or in batch reactors at laboratory scales [2,4]. However, these investigations were unable to provide clear evidence to understand the challenges posed by environmental factors. Furthermore, the capacity of anammox bacteria to adapt to unwanted toxic compounds in the anammox processes has not been systematically summarized and discussed.

Based on these current limitations in the literature, here, we systematically summarized and interpreted the performance of the anammox process for wastewater treatment focusing on operational conditions and environmental stress factors that may directly interfere with proper anammox performance. Up-to-date information regarding anammox studies on wastewater treatment has 
been summarized here to identify optimal strategies for the efficient operation of the anammox process, a critical aspect that is currently a focus of research.

\section{Effects of Operational Conditions on Anammox Performance}

\subsection{Temperature}

Temperature is one of the most important factors that strongly influences the anammox process. The fluctuation in temperature in the bioreactor can change the physical response of annamox and affects nitrogen removal efficiency [29,31-33] (Table 1). Temperature has a considerable effect on anammox growth and adaptation by controlling nitrogen removal, triggering many inhibitory effects, affecting microbial community structure, and influencing the stability of low nitrogen effluent when it is used in various bioreactors $[3,8,25,34]$. In the natural environment, anammox bacteria can be found in low $\left(-5\right.$ to $\left.4{ }^{\circ} \mathrm{C}\right)$ and high $\left(60\right.$ to $\left.80^{\circ} \mathrm{C}\right)$ temperature ranges [35-37]. The acclimation of anammox bacteria to a wide range of temperatures enables their applicability to various wastewater treatment systems.

The mainstream process is known to operate at a lower temperature, mostly around $15{ }^{\circ} \mathrm{C}$, to achieve a high nitrogen removal efficiency $(70 \%-90 \%)$ at low oxygen concentrations [38]. However, a previous study revealed that the application of the mainstream process with the PN/A process at low temperatures of $10-15{ }^{\circ} \mathrm{C}$ resulted in low nitrogen removal rates and often in increased nitrogen concentrations in the effluent [12], mainly in the form of nitrate. Decreasing the temperature can be beneficial to enable highly competitive nitrite-oxidizing bacteria (NOB), which are more active than $\mathrm{AOB}$, to produce more nitrate, despite the concentration ratio of $\mathrm{AOB}$ to $\mathrm{NOB}$ in the sludge being relatively constant [31]. In general, autotrophic nitrogen removal technologies in the mainstream process should be operated within temperatures ranges of $25^{\circ} \mathrm{C}$ to a maximum of $40^{\circ} \mathrm{C}$ as the optimal operating temperature.

At $30-40^{\circ} \mathrm{C}$, anammox bacteria can grow and perform better, preventing future adverse effects owing to inhibition and generating high organic carbon consumption to help reduce greenhouse gas emissions, especially of $\mathrm{CO}_{2}$ and $\mathrm{N}_{2} \mathrm{O}[22,25,27,39-41]$. When the temperature drops from 30 to $15^{\circ} \mathrm{C}$, or from 30 to $10^{\circ} \mathrm{C}$, the specific anammox activity declines by approximately ten-fold [31,42]. However, a study by Gilbert et al. [43] revealed that the specific activity of anammox was irregular and inconsistent while acclimating in temperatures of 10,20 , and $30^{\circ} \mathrm{C}$. A few studies also reported substrate inhibition by the availability of free ammonia, high concentration of nitrite, and toxic metals when operated at a high temperature of over $35^{\circ} \mathrm{C}[44,45]$. Some previous studies confirmed that a temperature range between $40-45^{\circ} \mathrm{C}$ can be detrimental to anammox bacteria, causing lysis in bacterial cells because of the release of cytochrome $\mathrm{c}$ after temperature shock and consequently reducing the anammox activity [40,42,46].

The optimal operating temperature for the sidestream anammox process has also been reported to be around $35-40^{\circ} \mathrm{C}$, higher than the temperature applied in the mainstream process [25,47]. The PN/A process in the sidestream wastewater treatment was also used for the treatment of dewatering liquor from anaerobic digesters fed with municipal and industrial wastewater [12]. Currently, PN/A is mainly used to remove ammonium in the effluent from anaerobic tanks in the mainstream process. Several studies have investigated full-scale sidestream anammox installations for the treatment of digested sewage, landfill leachate, and rejected water $[14,34,48]$. They found that the sidestream anammox process required high temperatures, usually higher than $30^{\circ} \mathrm{C}$, to generate high anammox activity and nitrogen removal efficiency $[8,30,43,49,50]$.

Recently, there is increasing interest in anammox performance at low temperatures to enable the use of the technology at high latitude regions at a temperature range of $10-20^{\circ} \mathrm{C}$ [31,41]. The cold anammox bacteria usually involved in temperatures around $5-6^{\circ} \mathrm{C}$ belong to Brocadia, particularly species "Candidatus Brocadia sinica" and "C. Brocadia fulgida" [31]. Anammox species "C. Kuenenia stuttgartiensis" was also found in a continuous bioreactor system at a temperature lower than $20^{\circ} \mathrm{C}$ [47]. 
Even though these anammox bacteria can acclimate to the temperature range of $10-12{ }^{\circ} \mathrm{C}$ [43], optimal activity is usually observed at warm temperature, between 18 and $23^{\circ} \mathrm{C}$, with high growth rate, high specific anammox activity, and less free ammonia and free nitrous acid [41]. Furthermore, at high latitudes, anammox bacteria decrease their growth rate owing to the decrease in enzyme activity, density of cytoplasm, and low mass transfer rate [12,49,51]. Moreover, operating anammox systems at low temperatures can stimulate an increase in the amount of ladderane fatty acids, which reduce membrane permeability and passive diffusion of protons out of the anammoxosome, and this prevents ATP synthesis, thereby reducing metabolism [41,52-54]. The instability of temperature in the mainstream and sidestream anammox processes makes extrapolation in operational design and maintenance challenging $[55,56]$.

Table 1. Influence of temperature and $\mathrm{pH}$ level on anammox performance.

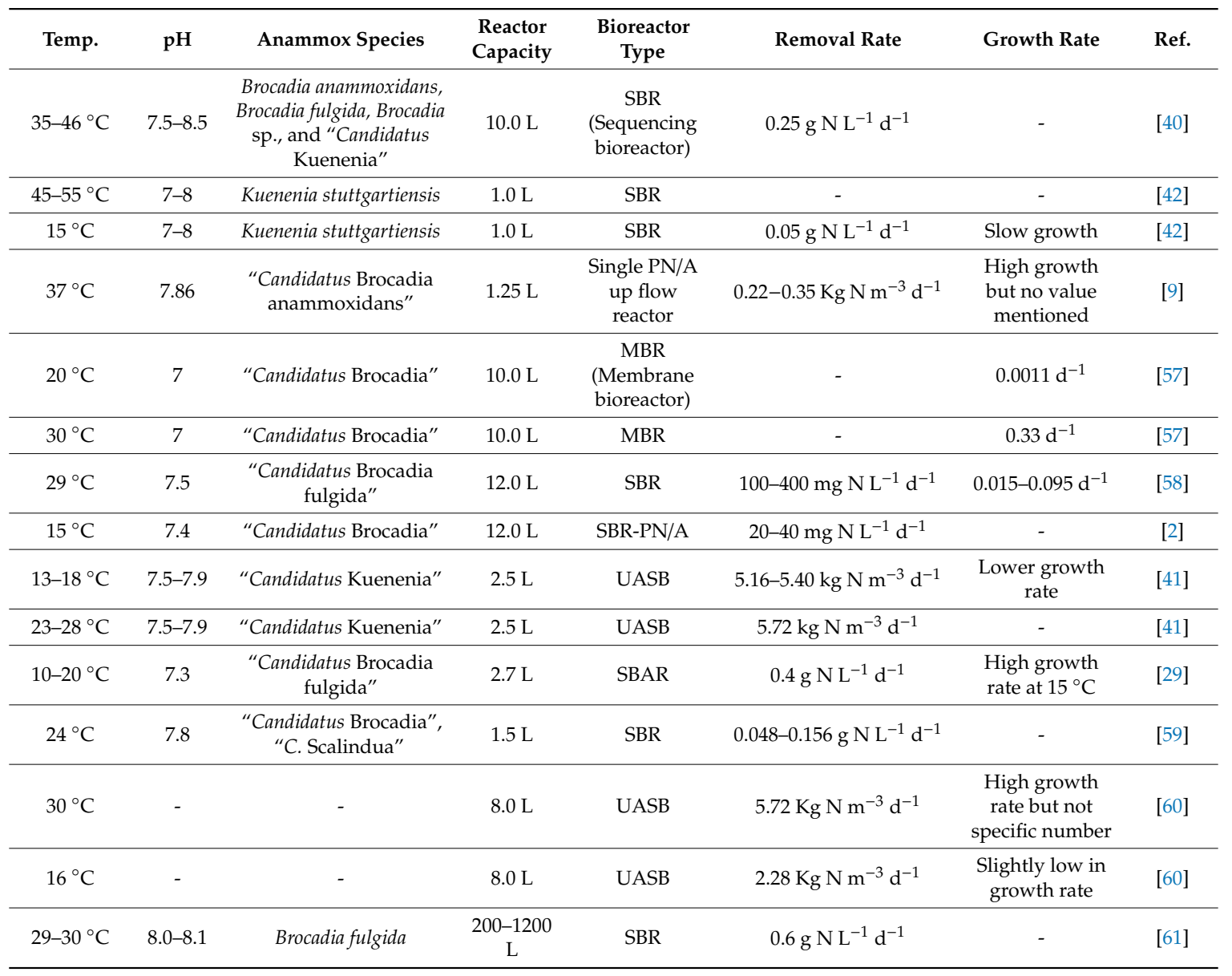

The capacity for growth in anammox bacteria is strongly influenced by temperature. Previous studies investigating the growth rate of both anammox bacteria and $\mathrm{AOB}$ at the temperature range between $20-30{ }^{\circ} \mathrm{C}$ observed that $\mathrm{AOB}$ had a higher growth rate than anammox $\left(0.7-0.9 \mathrm{~d}^{-1}\right.$ [62] vs. 0.05-0.09 $\mathrm{d}^{-1}[25,63]$, respectively). The slow growth of anammox bacteria $\left(10-12\right.$ days at $\left.35^{\circ} \mathrm{C}\right)$ limits their application at such temperature, particularly for influent with high concentrations of ammonium $[8,54,63]$. Unlike other microorganisms, anammox bacteria possess an extremely long reproduction time. Bacterial cells typically divide only once a week for a single cell or twice a week for aggregated cells $[52,64]$. However, the advantage of anammox bacteria is that the bacteria can be dormant if exposed to unfavorable conditions and become re-active under favorable conditions along with doubling time reached within 2 to 5 days [65]. When anammox bacteria have adapted to $15^{\circ} \mathrm{C}$, their biomass can easily increase by about two-fold and result in a higher nitrogen removal rate than the non-adapted anammox $[31,42,66]$. An ambient temperature of $21-25{ }^{\circ} \mathrm{C}$ was recommended to obtain 
a low nitrogen effluent in a single-stage anaerobic bioreactor [47], an up-flow column reactor [67], a municipal wastewater treatment reactor [12,56], and a sequencing batch reactor [33]. The presence of high diversity of anammox species resulted in various strategies for survival and adaptation being incorporated [3,33]. Brocadia and Kuenenia could adapt well to a low temperature range from $10-20^{\circ} \mathrm{C}$, but they also performed better at the temperature range of $20-30{ }^{\circ} \mathrm{C}$ [41] although their activity was lower than that at the optimal temperature of $30^{\circ} \mathrm{C}[8,33,42,67]$. A study by Lotti et al. [31] reported that the highest growth rate can be found at $30^{\circ} \mathrm{C}$, and the biomass was mostly occupied by "Candidatus Brocadia sp.", which is similar to findings in the mainstream PN/A step-feed activated sludge system operated in the Changi Water Reclamation Plant, Singapore [12] and in anammox membrane bioreactors operated at full scale in Rotterdam [57].

The solid retention time in the operational anammox process also plays an important role because it can affect specific anammox activity when the non-active and non-anammox cells in the reactor increased therein. Therefore, temperature control in the system should be considered with respect to solid retention time [57]. The operation of anammox membrane bioreactors at $37^{\circ} \mathrm{C}$, fed with low-ammonium influent (100 $\mathrm{mg}-\mathrm{N} / \mathrm{L})$, achieved high biomass and a high nitrogen removal rate compared to those at the same temperature but operated with an influent with higher ammonium content [8,68]. Activating the anammox population under such low nitrogen concentrations has become a strategy for the application of anammox for domestic wastewater treatment systems [69]. Thus far, the activation of anammox bacteria at such low or high temperatures is likely to depend on the adaptability of specific anammox species.

\section{2. $p H$}

The change in culture $\mathrm{pH}$ can influence the anammox process greatly owing to the accumulation of toxic compounds which inhibits anammox activity. Common $\mathrm{pH}$ values applied in anammox systems are listed in Table 1. Maintaining $\mathrm{pH}$ is an important aspect of sustaining high nitrogen removal over a long period [3,70]. Previous studies found that $\mathrm{pH}$ ranging from 6.5 to 8.3 can support growth and activity of anammox bacteria [25,67]. A review by Tomaszewsky et al. [71] suggested that a pH range of 7-8 is suitable to anammox and seems to be the ideal range for avoiding the inhibition of anammox by high free ammonia and free nitrous acid. For example, free ammonia concentration increased when $\mathrm{pH}$ was increased but a decrease facilitated accumulation of free nitrous acid. The low permeability of the anammox bacterial membrane and the limited diffusion ability of protons can protect the anammox bacteria from alkaline or acid conditions [37]. However, the anammox cell was observed to contain two compartments when cultured at different $\mathrm{pH}$ (6.3 and 7.3), revealing the presence of a proton motive force over the intracytoplasmic membrane [3]. A study by Jetten et al. [39] indicated that the optimum anammox activity and growth were obtained at the $\mathrm{pH}$ range of 6.7-8.3 and the maximum activity was found at $\mathrm{pH}$ up to 8.0.

The $\mathrm{pH}$ of the anammox enrichment culture also determined the dominant anammox bacteria in the anammox process. Brocadia anammoxidans and "Candidatus Anammoxoglobus propionicus" were observed to be dominant in the enrichment from aerobic granules and leachate sludge, respectively, when the $\mathrm{pH}$ of the enrichment culture was controlled from 6.8-7.0 [72]. However, anammox species "Candidatus Brocadia anammoxidans" [9,63,73-75] and Kuenenia stuttgartiensis [45,63] were found predominantly in anammox systems with $\mathrm{pH}$ of 7.8-8 [76]. Therefore, controlling $\mathrm{pH}$ closely coordinates the efficiency of nitrogen removal of anammox reactors. The implementation of anammox in a single bioreactor is a novel approach that can remove the nitrogen from both municipal and industrial wastewaters by controlling $\mathrm{pH}$ and dissolved oxygen through aeration [33,77]. The single-stage anammox process can achieve an energy-cost saving of $25 \%$ compared to the conventional process provided that stability of $\mathrm{pH}$ and aeration is controlled $[59,77]$. 


\subsection{Dissolved Oxygen (DO)}

Anammox bacteria conventionally grow and are active in critical DO regions, which has been proven by several studies in oxygen minimal zones [78-82]. Studies have investigated the anammox activity at a very low oxygen concentration, even below the detection limit $\left(0.01 \mathrm{mg} \mathrm{L}^{-1}\right)$, addressing the sensitivity of anammox bacteria to oxygen levels [34,81] (Table 2). Anoxic conditions or low oxygen concentrations support anammox metabolism particularly in terms of enzyme production $[78,81,82]$ and activate the induction of the anammox reaction [27,34]. The application of oxygen microelectrode profiling in the sequencing batch reactor (SBR) anammox system highlighted the influence of low oxygen levels on the size and type of anammox biomass [83]. Granular biomass anammox can produce a similar nitrogen removal rate of $600 \mathrm{mg} \mathrm{N} /(\mathrm{L} \cdot \mathrm{d})$ at both $\mathrm{DO}$ concentrations of 1 and $8 \mathrm{mg} / \mathrm{L}$, even though at the latter DO concentration, oxygen can fully penetrate the bacterial cells in the granular biomass [83]. In contrast, neither growth nor nitrogen removal was observed with an anammox biofilm exposed to a DO level of $8 \mathrm{mg} / \mathrm{L}$ in another study [84]. A study by Liu et al. [84] indicated that the anammox activity at a DO level lower than $0.04 \mathrm{mg} / \mathrm{L}$ can generate a high rate of nitrogen removal $\left(2.1 \mathrm{~kg} \mathrm{~N} /\left(\mathrm{m}^{3} \cdot \mathrm{d}\right)\right.$.

Table 2. Effect of dissolved oxygen (DO) on the performance of anammox systems.

\begin{tabular}{|c|c|c|c|c|c|}
\hline DO Level & Specific Bioreactor & $\begin{array}{l}\text { Reactor } \\
\text { Capacity }\end{array}$ & Problems & Removal Rate & Ref. \\
\hline $2-8 \mathrm{mg} \mathrm{O}_{2} \mathrm{~L}^{-1}$ & SBR & $2.6 \mathrm{~L}$ & $\begin{array}{l}\text { Increasing } \mathrm{O}_{2} \text { from } 2 \text { to } 8 \mathrm{mg} \mathrm{L}^{-1} \\
\text { decreased the removal rate }\end{array}$ & $46-380 \mathrm{~g} \mathrm{~N} \mathrm{~L}^{-1} \mathrm{~d}^{-1}$ & [61] \\
\hline$<0.04 \mathrm{mg} \mathrm{O}_{2} \mathrm{~L}^{-1}$ & $\begin{array}{l}\text { NRBC (non-woven } \\
\text { rotating biological } \\
\text { contactor) }\end{array}$ & $7 \mathrm{~L}$ & $\begin{array}{l}\text { Increasing } \mathrm{O}_{2} \text { in the system reduced the } \\
\mathrm{AOB} \text { activity, nitrogen removal rate, and } \\
\text { caused high nitrite concentrations }\end{array}$ & $2.1 \mathrm{~kg} \mathrm{~N} \mathrm{~L}^{-1} \mathrm{~d}^{-1}$ & [84] \\
\hline$<0.3 \mathrm{mg} \mathrm{O}_{2} \mathrm{~L}^{-1}$ & SBR & $10 \mathrm{~L}$ & $\begin{array}{l}\text { Suspended anammox biomass activity } \\
\text { inhibited by low temperature }\end{array}$ & $6-8 \mathrm{mg} \mathrm{N} \mathrm{L}^{-1} \mathrm{~d}^{-1}$ & [43] \\
\hline $0.4 \mathrm{mg} \mathrm{O}_{2} \mathrm{~L}^{-1}$ & SBR & $1200 \mathrm{~L}$ & $\begin{array}{l}\text { Thin layers of granules can easily be } \\
\text { penetrated by oxygen }\end{array}$ & $0.6 \mathrm{~g} \mathrm{~N} \mathrm{~L}^{-1} \mathrm{~d}^{-1}$ & [83] \\
\hline $3.0 \mathrm{mg} \mathrm{O}_{2} \mathrm{~L}^{-1}$ & SBR & $200 \mathrm{~L}$ & $\begin{array}{l}\text { More difficult for oxygen to penetrate } \\
\text { thick layers and it protected anammox } \\
\text { from non-suitable liquid media } \\
\text { conditions (benefit to anammox) }\end{array}$ & $0.6 \mathrm{~g} \mathrm{~N} \mathrm{~L}^{-1} \mathrm{~d}^{-1}$ & [83] \\
\hline $0.4-4 \mathrm{mg} \mathrm{O}_{2} \mathrm{~L}^{-1}$ & SBR & $10 \mathrm{~L}$ & Appearance of $\mathrm{AOB}$ in anoxic conditions & $0.25 \mathrm{~g} \mathrm{~N} \mathrm{~L}^{-1} \mathrm{~d}^{-1}$ & [40] \\
\hline $0.18 \mathrm{mg} \mathrm{O}_{2} \mathrm{~L}^{-1}$ & $\begin{array}{l}\text { SBR-MBBR } \\
\text { (moving bed } \\
\text { biofilm reactor) }\end{array}$ & $12 \mathrm{~L}$ & $\begin{array}{l}\text { High nitrite and ammonia concentrations } \\
\text { during low temperature, }<11^{\circ} \mathrm{C}, \\
\text { anammox activity decreases }\end{array}$ & $0.047 \mathrm{~g} \mathrm{~N} \mathrm{~L}^{-1} \mathrm{~d}^{-1}$ & [2] \\
\hline $0.15 \mathrm{mg} \mathrm{O}_{2} \mathrm{~L}^{-1}$ & SBR-HMBBR & $12 \mathrm{~L}$ & $\begin{array}{l}\text { High nitrite and ammonia concentrations } \\
\text { during low temperature, }<11^{\circ} \mathrm{C}, \\
\text { anammox activity decreases }\end{array}$ & $0.026 \mathrm{~g} \mathrm{~N} \mathrm{~L}^{-1} \mathrm{~d}^{-1}$ & [2] \\
\hline $0.4 \mathrm{mg} \mathrm{O}_{2} \mathrm{~L}^{-1}$ & $\begin{array}{l}\text { CFR (continuous } \\
\text { flow reactor) }\end{array}$ & $12 \mathrm{~L}$ & $\begin{array}{l}\text { Slow response of anammox because of } \\
\text { lower loading rate and low anammox } \\
\text { biomass }\end{array}$ & $0.42 \mathrm{~g} \mathrm{NH}_{4}-\mathrm{N} \mathrm{L}^{-1}$ & [85] \\
\hline
\end{tabular}

Increasing the DO level gradually could be a better operational strategy to increase the adaptability of anammox and other symbiont bacteria within the system. Liu et al. [84] provided a strategy based on the anammox symbiont and other oxygen-consuming bacteria such as Nitrosomonas eutropha to create anoxic conditions for anammox bacteria activity. Wang et al. [86] and Liu et al. [84], using fluorescent in situ hybridization analysis, observed that the anammox bacterial population reached $70 \%$ of total bacteria in biofilms after the oxygen adaptation stage. This suggested that the application of anammox in an environment with moderate DO level in the presence of symbiont bacteria could be considered. Controlling the DO levels in the reactor would support the oxidation of ammonium to nitrite and prevent the oxidation of nitrite to nitrate, which is challenging for the anammox reaction $[77,87]$.

When a stable DO level is maintained in the reactor, the conversion rate of ammonium to nitrite and nitrite to nitrate was found to be different owing to the diversified population of AOB and NOB in various systems [56]. The common AOB found in the anammox system were Nitrosomonas eutropha, 
N. europaea, and Nitrosospira sp. [77]. Nitrosomonas was reported to be the dominant genus of AOB. It can uptake oxygen faster and exist in the anammox system for a long period to enhance the nitritation process. In addition, $N$. eutropha is beneficial to the anammox system in that it protects anammox bacteria from oxygen inhibition $[84,88]$.

\subsection{Nitrogen Loading}

Besides temperature, $\mathrm{pH}$, and $\mathrm{DO}$, nitrogen concentration is another important factor directly affecting the anammox process. Some previous studies revealed that various loading rates of nitrogen in the form of ammonium can considerably influence nitrogen removal rate, growth capability, dominant bacterial species, and optimization potential of the long-term anammox process [20,59] (Table 3). Ammonium concentration was responsible for the successful growth of anammox bacteria and their nitrogen removal capability; however, the ammonium concentration should be correlated to the density of anammox bacteria. Low ammonium concentration coupled with high cell density would result in low anammox activity [25]. In contrast, the supply of improper ammonium and nitrite levels would stimulate the growth of unwanted bacteria, thereafter interfering with anammox activity [25].

Table 3. Effect of nitrogen loading on the performance of anammox systems.

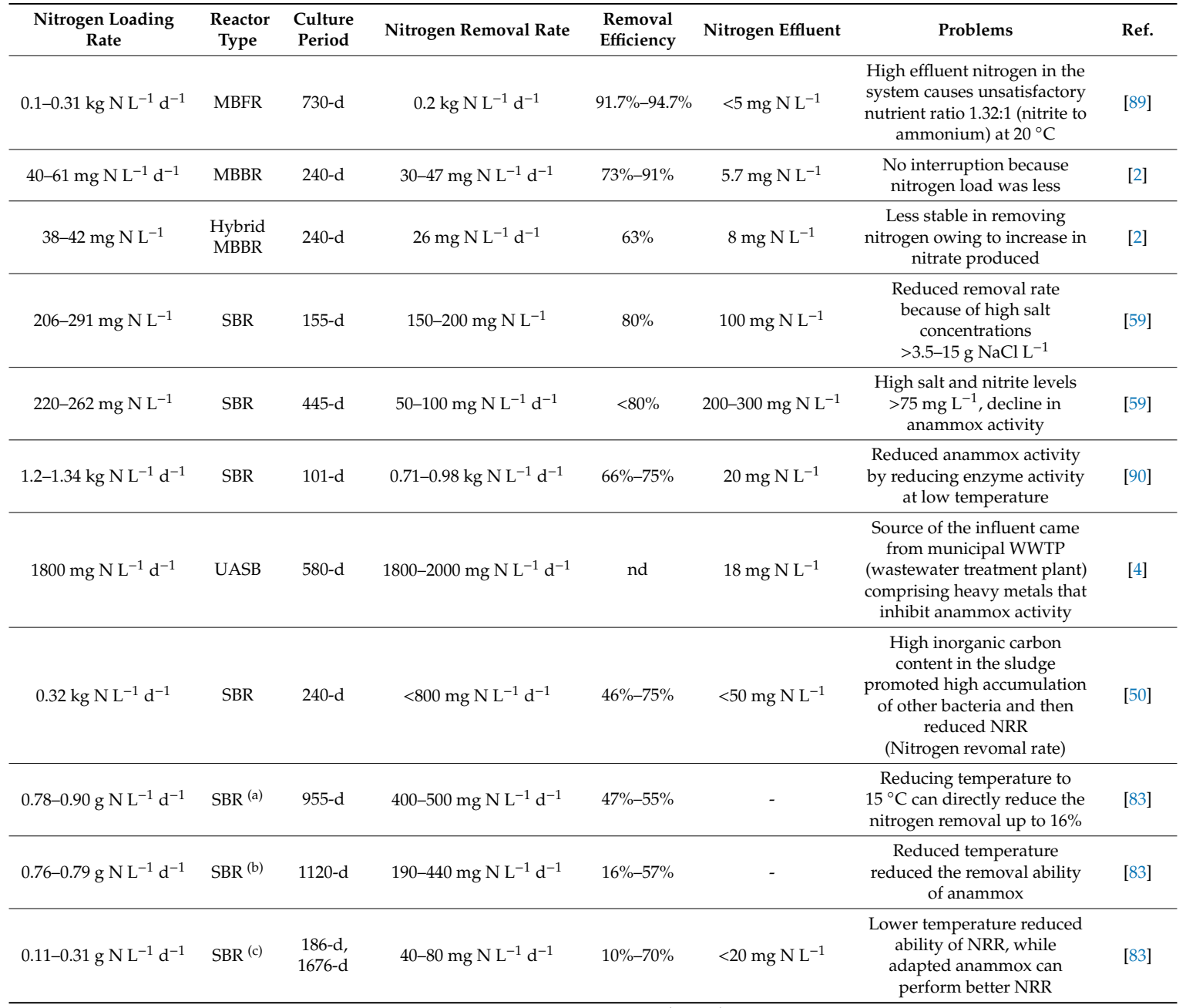

(a) Operated at $20{ }^{\circ} \mathrm{C}$ with nitrogen concentration $200 \mathrm{mg} \mathrm{NH}^{4+} \mathrm{L}^{-1}$, (b) at $15^{\circ} \mathrm{C}$ with nitrogen concentration $200 \mathrm{mg} \mathrm{NH}^{4+} \mathrm{L}^{-1}$, (c) at $15{ }^{\circ} \mathrm{C}$ with nitrogen concentration $50-75 \mathrm{mg} \mathrm{NH}^{4+} \mathrm{L}^{-1}$.

Anammox bacteria preferred a low nitrogen concentration for faster activation [71]. The abundant availability of nitrite and nitrate (higher than $0.07 \mathrm{~g} / \mathrm{L}$ ) at an early stage can interrupt anammox growth, whereas a lower nitrite concentration (up to $0.04 \mathrm{~g} / \mathrm{L}$ ) can enhance anammox growth and specific 
anammox activity [71]. The maximum specific anammox activity ( $0.035 \mathrm{~g} \mathrm{~N} /(\mathrm{g}$ VSS·h) was obtained in an SBR when the nitrogen concentration was controlled close to the stoichiometric nitrite/ammonium molar ratio (1.32) [91]. Free ammonia level of 35-40 mg N/L [43,92] or 20-30 mg N/L [93] could decrease anammox activity by up to $50 \%$. Both ammonium and nitrite concentrations in the range of several hundred milligrams per liter [26] to several grams per liter [34] can influence anammox activity regardless of loading rates.

As with temperature, anammox bacteria need to be acclimatized to adapt to high or low nitrogen concentrations in order to support anammox metabolism and removal capability. Adapted anammox bacteria in an SBR bioreactor could remove up to 70\% of nitrogen at a concentration load of $1 \mathrm{~g}$ $\mathrm{NH}_{4}-\mathrm{N} / \mathrm{L}$ over 60 days [61], whereas $80 \%$ nitrogen removal efficiency was achieved within 30 days in the anammox reactor fed with fish-canning wastewater containing 0.105 and $0.203 \mathrm{~g} \mathrm{~N} / \mathrm{L}$ [59]. In addition, $87 \%$ nitrogen removal was successfully achieved after $150 \mathrm{~d}$ of operation with influent of $0.2 \mathrm{~g} \mathrm{~N} / \mathrm{L}$ and $9.2 \mathrm{~g} / \mathrm{L}$ of $\mathrm{NaCl}$ [59]; however, when a high nitrogen loading rate of $1.7 \mathrm{~kg} \mathrm{~N} /\left(\mathrm{m}^{3} \cdot \mathrm{d}\right)$ coupled with high $\mathrm{NaCl}$ concentration of $30 \mathrm{~g} / \mathrm{L}$ was introduced to the reactor, the nitrogen removal rate decreased significantly owing to the deterioration of anammox bacteria under severe hypersaline inhibition. High salinity can inhibit the synthesis of many enzymes and decrease cell metabolism via plasmolysis [22]. However, the appropriate addition of salt to the influent can mitigate the effect of high nitrogen loading into anammox reactors.

With the ultimate aim to mitigate the limitation of the anammox process for treating wastewater containing high nitrogen concentration, anammox bacteria were introduced in reactors of various types and capacities to observe treatment efficiency and energy consumption [43]. Operation of the anammox process with different sources of biomass should be applied using different adaptation strategies. The anammox process operated with a granular sludge will adapt to a nitrogen level different from that operated with suspended anammox biofilms. Anammox bacteria in the form of large granules will be less affected by nitrogen concentration than a smaller anammox biofilm [43]. Previous studies reported that a granular anammox sludge can remove $80 \%$ ammonium, corresponding to a maximum removal rate of $14 \mathrm{~kg} \mathrm{~N} /\left(\mathrm{m}^{3} \cdot \mathrm{d}\right)$ [94], whereas a suspended anammox biofilm can achieve an average removal rate of $12 \mathrm{~kg} \mathrm{~N} /\left(\mathrm{m}^{3} \cdot \mathrm{d}\right)$ [95]. Such a high rate of nitrogen removal by the suspended anammox biofilm could be because of the high cell density [96]. Furthermore, there are many other micro-environmental factors simultaneously affecting the performance of anammox systems including organic matter and DO concentration in the influent, mass transfer capability of biofilms, and micro-environment in the bioreactor as well as aeration strategy $[43,95]$. To avoid any interruption to the anammox process for a long period, a progressive adaptation of anammox biomass to particular bioreactors with various nitrogen concentrations and nitrogen loadings is required for process optimization $[61,83,96]$.

\subsection{Carbon Sources}

Municipal wastewater usually contains a certain amount of organic matter. However, the availability of high levels of organic carbon in the sludge waste somehow reduces the efficiency of anammox activity [70]. The anammox process is well recognized as a cost-efficient and sustainable alternative for nitrogen removal from wastewater sources with low $\mathrm{C} / \mathrm{N}$ ratios [56]. The investigation on the effect of the form of nitrogen such as ammonium, nitrate, and nitrite in anammox systems has been widely conducted; however, there is little information on the effect of organic carbon to nitrogen $(\mathrm{C} / \mathrm{N})$ ratio (Table 4). Jin et al. [22] systematically summarized previous studies on the inhibition of anammox activity by toxic and non-toxic organic compounds. Anammox activity could not be sustained at $\mathrm{COD} / \mathrm{N}$ ratios higher than 2 in a membrane-aerated biofilm reactor [13]. At the same COD/N ratio, rate of nitrogen removal decreased by $50 \%$ in a co-diffusion conventional biofilm reactor [13]. The availability of high organic matter in the wastewater treatment system has a negative effect on removal of ammonium by the anammox process owing to the competition between anammox bacteria and heterotrophic denitrifying bacteria. Anammox symbionts can typically oxidize a multitude of organic compounds with simultaneous reduction in nitrate and/or nitrite [97-101]. During the 
anammox operation, cell lysis or solubilization of unwanted material in the system resulted in the increase of organic matter from $6 \pm 2 \mathrm{mg} / \mathrm{L}$ to $327 \pm 21 \mathrm{mg} / \mathrm{L}$, and this directly reduced the performance of anammox bacteria [77]. The study by García-Ruiz et al. [102] revealed that the nitrogen removal efficiency was not affected by the organic carbon level of $100 \mathrm{mg}$ COD (chemical oxygen demand) $\mathrm{L}^{-1}$ during the operation of a CANON biofilter system in which coexisting AOB, anammox, and denitrifiers were fed with an influent with an ammonium concentration of $320 \mathrm{mg} / \mathrm{L}$. However, the operation of the same bioreactor without organic carbon in the presence of anammox and AOB showed a significant decrease in nitrogen removal efficiency. The study by Kartal et al. [103] showed the possibility of a metabolic pathway for anammox using carbon as a substrate in the presence of heterotrophic denitrifiers. Anammox bacteria can benefit under this condition because these denitrifiers consume oxygen to metabolize the organic carbon [104]. Anammox bacteria "Candidatus Anammoxoglobus propionicus" was found to out-compete other denitrifiers for propionate as the electron donor [103]. "Candidatus Brocadia fulgida" can consume some organic carbon forms such as propionate, formate, and dimethylamine [105].

Table 4. Effect of nitrogen loading on the performance of anammox systems.

\begin{tabular}{|c|c|c|c|c|c|c|}
\hline $\begin{array}{l}\text { Influent Carbon } \\
\text { (COD/IC) }\end{array}$ & $\begin{array}{l}\text { Reactor } \\
\text { Type }\end{array}$ & $\begin{array}{l}\text { Culture } \\
\text { Period }\end{array}$ & $\begin{array}{l}\text { Carbon } \\
\text { Concentration } \\
\text { Effluent }\end{array}$ & $\begin{array}{c}\text { Nitrogen } \\
\text { Removal } \\
\text { Efficiency/ } \\
\text { Effluent Nitrogen }\end{array}$ & Problems & Ref. \\
\hline $\begin{array}{l}\text { 70.6-284.1 COD mg } \\
\mathrm{L}^{-1} \\
\end{array}$ & $\mathrm{ABR}$ & $91 \mathrm{~d}$ & $50 \mathrm{mg} \mathrm{L}^{-1}$ & $89 \%-96 \%$ & $\begin{array}{l}\text { High COD concentration } \\
\text { damages the anammox activity }\end{array}$ & [106] \\
\hline $100 \mathrm{mg}$ COD $\cdot \mathrm{L}^{-1}$ & CANON & $60 \mathrm{~d}$ & nd & $85 \%$ & $\begin{array}{l}\text { Lower carbon resulted in high } \\
\text { removal rate }\end{array}$ & [102] \\
\hline $400 \mathrm{mg} \mathrm{COD} \mathrm{L}^{-1}$ & CANON & $60 \mathrm{~d}$ & nd & $68.1 \%$ & $\begin{array}{l}\text { Partial inhibition of nitrogen } \\
\text { removal rate and increase in the } \\
\text { heterotrophic bacteria }\end{array}$ & [102] \\
\hline $533 \mathrm{mg} \mathrm{COD} \mathrm{L}^{-1}$ & MBBR & $280 \mathrm{~d}$ & $40 \mathrm{mg} \mathrm{COD} \mathrm{L}^{-1}$ & $73 \%-91 \%$ & $\begin{array}{l}\text { No interruption because nitrogen } \\
\text { load was less }\end{array}$ & [2] \\
\hline $533 \mathrm{mg} \mathrm{COD} \mathrm{L}^{-1}$ & $\begin{array}{l}\text { Hybrid } \\
\text { MBBR }\end{array}$ & $210 \mathrm{~d}$ & $33 \mathrm{mg} \mathrm{COD} \mathrm{L}{ }^{-1}$ & $63 \%$ & $\begin{array}{l}\text { Less stable in removing nitrogen } \\
\text { owing to increase in nitrate } \\
\text { produced }\end{array}$ & [2] \\
\hline $60 \mathrm{mg} \mathrm{IC} \mathrm{L}^{-1}$ & $\begin{array}{l}\text { Fixed bed } \\
\text { Reactor }\end{array}$ & $39 \mathrm{~d}$ & nd & $4-4.5 \mathrm{~kg} \mathrm{~N} \mathrm{~L}^{-1} \mathrm{~d}^{-1}$ & High IC reduced the NRR & [107] \\
\hline$<10 \mathrm{mg} \mathrm{IC} \mathrm{L}^{-1}$ & $\begin{array}{l}\text { Fixed bed } \\
\text { Reactor }\end{array}$ & $39 \mathrm{~d}$ & $4 \mathrm{mg} \mathrm{C} \mathrm{L}^{-1}$ & $3.5 \mathrm{~kg} \mathrm{~N} \mathrm{~L}^{-1} \mathrm{~d}^{-1}$ & $\begin{array}{l}\text { Low IC reduced the anammox } \\
\text { removal of nitrogen, the NRR, } \\
\text { and the saturation found at } \\
\qquad 1.2 \mathrm{mg} \mathrm{L}^{-1}\end{array}$ & [107] \\
\hline $90 \mathrm{mg} \mathrm{IC} \mathrm{L}^{-1}$ & $\begin{array}{l}\text { Lab Scale } \\
\text { PN/A }\end{array}$ & $40 \mathrm{~d}$ & nd & $78 \%$ & $\begin{array}{l}\text { Low nitrite was produced } \\
\text { because of imbalance in bacterial } \\
\text { population in the process }\end{array}$ & [108] \\
\hline $9.6 \mathrm{mg} \mathrm{IC} \mathrm{L}^{-1}$ & $\begin{array}{l}\text { Lab Scale } \\
\text { PN/A }\end{array}$ & $86 \mathrm{~d}$ & nd & $46 \%$ & $\begin{array}{l}\text { Anammox was outcompeted by } \\
\text { NOB for nitrite; then, nitrate } \\
\text { becomes abundant }\end{array}$ & [108] \\
\hline
\end{tabular}

In contrast to organic carbon, studies on the role of inorganic carbon in the anammox process are still limited. The limitation of inorganic carbon hindered the reproduction of anammox bacteria and thereafter delayed the performance of anammox [18,107]. The limitation of inorganic carbon and the competition for organic carbon with other symbiont bacteria is a challenge in the maintenance of the mainstream anammox process.

\section{Effect of Environmental Stresses on Anammox Performance}

\subsection{Inhibition by Nitrite}

According to the anammox equation, the theoretical ratio of nitrite to ammonium is 1.32:1. Although nitrite is an essential substrate for the anammox process, nitrite becomes toxic to some anammox bacteria $[109,110]$ when it is accumulated in the anammox systems owing to the shortage 
of ammonium for a theoretical anammox reaction. The nitrite inhibition level varied in different anammox systems and with different anammox inoculation sources (Table 5). The highest nitrite concentration tested for anammox was $1000 \mathrm{mg} / \mathrm{L}$ [111]. Anammox sludge dominated by "C. Brocadia" in a serum bottle was found to be totally inhibited when introduced to $1000 \mathrm{mg} / \mathrm{L} \mathrm{of} \mathrm{NO}_{2}{ }^{-}-\mathrm{N}^{-}$and in the batch test, and its activity decreased by $50 \%$ at a nitrite concentration of $400 \mathrm{mg} / \mathrm{L}$ [111]. The nitrite concentration where activity of anammox is decreased by $50 \%$ is commonly referred to as $\mathrm{IC}_{50}$. The IC $\mathrm{IC}_{50}$ was also different for different anammox inoculum sources. In the same investigation with different anammox inoculation sources, UASB granular sludge was found to have the highest $\mathrm{IC}_{50}(240 \mathrm{mg} / \mathrm{L})$, whereas the $\mathrm{IC}_{50}$ with MBBR (moving bed biofilm reactor) biofilms and SBR sludge was 85 and $98 \mathrm{mg} / \mathrm{L}$, respectively [112]. The $\mathrm{IC}_{50}$ for the anammox biomass dominated by "Candidatus Kuenenia stuttgartiensis" in a batch test using serum vial was found to be $350 \mathrm{mg} / \mathrm{L} \mathrm{[26].} \mathrm{The} \mathrm{IC}_{50}$ value was not significantly different among physical types (suspended and granular) of anammox bacteria in a serum batch-test [113]. In contrast, the presence/absence of ammonium in the culture medium significantly affected the $\mathrm{IC}_{50}$ value [109]. In the presence of ammonium, $384 \mathrm{mg} / \mathrm{L}$ of nitrite could decrease the activity of anammox bacteria by $50 \%$. However, in the absence of ammonium, only $53 \mathrm{mg} / \mathrm{L}$ of nitrite could inhibit $50 \%$ anammox bacterial activity.

Table 5. Effect of nitrite on anammox performance.

\begin{tabular}{|c|c|c|c|c|c|}
\hline Seeding Sources & Reactor & $\begin{array}{l}\text { Operation } \\
\text { Mode }\end{array}$ & $\begin{array}{c}\mathrm{NO}_{2}{ }^{-}-\mathrm{N} \\
\text { Concentration } \\
(\mathrm{mg} / \mathrm{L})\end{array}$ & Effect & Ref. \\
\hline $\begin{array}{l}\text { Anammox sludge dominated } \\
\text { by Brocadia }\end{array}$ & Serum bottle & Batch test & $\begin{array}{c}400 \\
1000\end{array}$ & $\begin{array}{l}\text { Inhibition by } 50 \% \\
\text { Total inhibition }\end{array}$ & [111] \\
\hline $\begin{array}{l}\text { Anammox sludge from pilot } \\
\text { scale SBR }(40 \mathrm{~L})\end{array}$ & 1.1-L reactor & Batch test & $\begin{array}{l}30 \\
60\end{array}$ & $\begin{array}{l}\text { Losses in activity } \\
\text { Maximum nitrite } \\
\text { removal rate } \\
\text { decreased by } 25 \%\end{array}$ & [114] \\
\hline $\begin{array}{l}\text { Anammox biomass } \\
\text { dominated by "Candidatus } \\
\text { Kuenenia stuttgartiensis" }\end{array}$ & Serum vial & Batch test & 350 & Inhibition by $50 \%$ & [26] \\
\hline Anammox biofilm & $\begin{array}{l}\text { SBR reactor } \\
5 \mathrm{~L}\end{array}$ & Continuous & $<240$ & No inhibition & [55] \\
\hline $\begin{array}{l}\text { Anaerobic granular sludge } \\
\text { from UASB (upflow anaerobic } \\
\text { sludge blanket reactor) reactor }\end{array}$ & UBF reactor & Continuous & 380 & $\begin{array}{l}\text { Nitrogen removal } \\
\text { sharply decreased }\end{array}$ & {$[70]$} \\
\hline $\begin{array}{c}\text { Anammox sludge entrapped } \\
\text { in a polyethylene glycol (PEG) } \\
\text { gel carrier }\end{array}$ & $\begin{array}{l}\text { Cylindrical } \\
\text { reactor } \\
(500 \mathrm{~mL})\end{array}$ & Continuous & 750 & $\begin{array}{l}\text { Activity decreased } \\
\text { by } 10 \%\end{array}$ & [115] \\
\hline Granular anammox sludge & Serum bottle & Batch test & 561 & Inhibition & {$[92]$} \\
\hline $\begin{array}{c}\text { MBBR biofilm } \\
\text { SBR sludge } \\
\text { UASB granular sludge }\end{array}$ & $\begin{array}{l}\text { Air-tight } 800 \\
\text { mL bottle }\end{array}$ & Batch test & $\begin{array}{c}85 \\
98 \\
240\end{array}$ & $\begin{array}{l}\text { Inhibition by } 50 \% \\
\text { Inhibition by } 50 \% \\
\text { Inhibition by } 50 \%\end{array}$ & [112] \\
\hline $\begin{array}{l}\text { Biofilm carriers taken from the } \\
\text { MBBR }\end{array}$ & $1.2 \mathrm{~L}$ vessel & Batch test & $\begin{array}{l}100 \\
160\end{array}$ & $\begin{array}{c}\text { Activity decreased } \\
\text { by } 26 \% \\
\text { Total inhibition }\end{array}$ & [116] \\
\hline $\begin{array}{l}\text { Suspended anammox culture } \\
\text { Granular anammox } \\
\text { enrichment }\end{array}$ & $\begin{array}{l}\text { Serum flask } \\
\quad(160 \mathrm{~mL})\end{array}$ & Batch test & $\begin{array}{l}151 \\
185\end{array}$ & $\begin{array}{l}\text { Inhibition by } 50 \% \\
\text { Inhibition by } 50 \%\end{array}$ & [113] \\
\hline Anammox granular sludge & $\begin{array}{l}\text { Serum flasks } \\
\quad(160 \mathrm{~mL})\end{array}$ & Batch test & $\begin{array}{r}53 \\
384\end{array}$ & $\begin{array}{l}\text { Inhibition by } 50 \% \text { in } \\
\text { the absence of } \\
\text { ammonium } \\
\text { Inhibition by } 50 \% \text { in } \\
\text { the presence of } \\
\text { ammonium }\end{array}$ & [109] \\
\hline $\begin{array}{l}\text { Loose biomass taken from the } \\
\text { MBBR }\end{array}$ & $\begin{array}{l}\text { Serum flask } \\
\quad(800 \mathrm{~mL})\end{array}$ & Batch test & 52 & $\begin{array}{l}\text { Activity decreased } \\
\text { by }>35 \%\end{array}$ & [117] \\
\hline
\end{tabular}


As summarized in Table 5, the inhibition concentration of nitrite seems to be higher in the continuous test than in the batch test. No inhibition was observed for anammox bacteria at nitrite concentrations lower than $240 \mathrm{mg} / \mathrm{L}$ in a $5 \mathrm{~L}$ SBR reactor [55]. Anammox bacterial activity decreased by only $10 \%$ at a nitrite concentration of $750 \mathrm{mg} / \mathrm{L}$ in a cylindrical reactor operated with a continuous mode [115], at which nitrite concentration and anammox bacteria in most of the batch operations decreased by $50 \%$. In another study with a continuous UBF (upflow blanket filter) reactor, nitrogen removal by the anammox granular sludge decreased sharply at $380 \mathrm{mg} / \mathrm{L}$ of nitrite [114].

The most nitrite-sensitive anammox bacteria were found in a batch test in a $1.1 \mathrm{~L}$ reactor with inoculum taken from a pilot-scale SBR $(40 \mathrm{~L})$, where the anammox activity was lost from the nitrite concentration of $30 \mathrm{mg} / \mathrm{L}$ onward [114]. When nitrite concentration increased to $60 \mathrm{mg} / \mathrm{L}$, nitrite removal rate decreased by $25 \%$. Total anammox activity inhibition was reported in a batch test with anammox biofilm carriers taken from an MBBR with nitrate concentration of $160 \mathrm{mg} / \mathrm{L}$ [116] which is quite a low concentration compared to that in other studies. However, in the same experiment with a nitrite concentration of $100 \mathrm{mg} / \mathrm{L}$, anammox activity decreased by only $26 \%$. Generally, the effect of nitrite concentration on anammox bacteria activity cannot be predicted and can only be determined through experimentation. In order to maintain effective performance of the anammox system, nitrite concentration should be controlled at an appropriate threshold which is determined previously.

\subsection{Inhibition by Sulfide}

Sulfide is commonly found in an anaerobic wastewater system owing to the degradation of organic matter and reduction in sulfate under anaerobic conditions. Understanding the effect of sulfide on activities of anammox bacteria is necessary for the operation of an anammox system. However, the number of studies on sulfide inhibition is more limited than those on nitrite inhibition. In a batch test with anammox granular sludge in serum bottles, anammox bacterial activity was halved when influent with $264 \mathrm{mg} / \mathrm{L}$ of sulfide-S was added [51] (Table 6). The same anammox seeding source in an UASB (upflow anaerobic sludge blanket reactor) reactor with continuous influent containing $40 \mathrm{mg} / \mathrm{L}$ of sulfide-S showed a decrease of $17.2 \%$ in nitrogen removal activity. This indicated a significant difference in the effect of sulfide on the same anammox bacterial community when the operation mode and reactor were changed. Total anammox activity inhibition was reported at $160 \mathrm{mg} / \mathrm{L}$ of sulfide-S [26] in a batch test using serum vials and anammox biomass dominated by "Candidatus Kuenenia stuttgartiensis". However, in another study, anammox mixed sludge exposed to $192 \mathrm{mg} / \mathrm{L}$ of sulfide-S only showed a decrease of $35.6 \%$ in nitrogen removal activity [118]. The percentage decrease in anammox activity is in proportion to the increase in sulfide-S concentration in the anammox system. In most cases, anammox activity can recover when no more sulfide exists in the influent. However, exposure of anammox to sulfide- $\mathrm{S}$ of $320 \mathrm{mg} / \mathrm{L}$ resulted in irreversible inhibition [113].

In fact, the toxic effect of sulfide was found to be attributed to unionized sulfides (soluble $\mathrm{H}_{2} \mathrm{~S}$ ) and not ionized forms such as $\mathrm{HS}^{-}$and $\mathrm{S}^{2-}$. A small concentration of soluble $\mathrm{H}_{2} \mathrm{~S}$ could significantly inhibit anammox activity. The $\mathrm{IC}_{50}$ of soluble $\mathrm{H}_{2} \mathrm{~S}$ was found to be $1.023 \mathrm{mg} / \mathrm{L}$ for suspended anammox enrichment culture in serum flasks for a batch test [113]. This number was slightly higher for granular anammox enrichment in the same investigation. The concentration of soluble $\mathrm{H}_{2} \mathrm{~S}$ is typically dependent on the $\mathrm{pH}$ of the medium, total sulfide added, and the headspace to liquid volume ratio, and can be calculated using these values [113]. Therefore, the control of the amount of unionized sulfide in the anammox system is more important than that of the total sulfide in the influent. In the anammox system, there could be a joint toxic effect from various inhibitors [118]. This joint toxicity could be antagonistic or synergistic. The inhibitory effect of sulfide to anammox granular sludge in a serum bottle was observed to be generally synergistic with oxytetracycline and phenol, both of which can be potentially found in wastewater [118]. 
Table 6. Effect of sulfide on anammox performance.

\begin{tabular}{|c|c|c|c|c|c|}
\hline Seeding Sources & Reactor & $\begin{array}{l}\text { Operation } \\
\text { Mode }\end{array}$ & $\begin{array}{c}\text { Sulfide-S } \\
\text { Concentration } \\
(\mathrm{mg} / \mathrm{L})\end{array}$ & Effect & Ref. \\
\hline $\begin{array}{c}\text { Suspended } \\
\text { enrichment culture } \\
\text { Granular anammox } \\
\text { enrichment }\end{array}$ & Serum flasks & Batch test & $\begin{array}{l}1.023\left(\mathrm{H}_{2} \mathrm{~S}\right) \\
3.751\left(\mathrm{H}_{2} \mathrm{~S}\right)\end{array}$ & $\begin{array}{l}\text { Inhibition by } 50 \% \\
\text { Inhibition by } 50 \%\end{array}$ & [113] \\
\hline $\begin{array}{l}\text { Anammox granular } \\
\text { sludge }\end{array}$ & $\begin{array}{l}\text { Serum bottles } \\
\text { Up-flow anaerobic } \\
\text { sludge blanket } \\
\text { reactor }\end{array}$ & $\begin{array}{l}\text { Batch test } \\
\text { Continuous }\end{array}$ & $\begin{array}{c}264 \\
40\end{array}$ & $\begin{array}{c}\text { Inhibition by } 50 \% \\
\text { Activity decreased by } 17.2 \%\end{array}$ & [51] \\
\hline $\begin{array}{l}\text { Anammox mixed } \\
\text { sludge }\end{array}$ & Serum bottles & Batch test & $\begin{array}{c}48 \\
96 \\
192 \\
\end{array}$ & $\begin{array}{l}\text { Activity decreased by } 14.0 \% \\
\text { Activity decreased by } 21.2 \% \\
\text { Activity decreased by } 35.6 \%\end{array}$ & [118] \\
\hline $\begin{array}{l}\text { Anammox biomass } \\
\text { dominated by } \\
\text { “Candidatus Kuenenia } \\
\text { stuttgartiensis" }\end{array}$ & Serum vial & Batch test & 160 & Total inhibition & [26] \\
\hline $\begin{array}{l}\text { Suspended and } \\
\text { granular anammox } \\
\text { culture }\end{array}$ & Serum flasks & Batch test & 320 & Irreversible inhibition & [113] \\
\hline
\end{tabular}

\subsection{Inhibition by Toxic Metals}

Toxic metals are usually present in some types of wastewater such as landfill leachate and industrial discharge. It is well-known that a high concentration of metals is normally toxic to microorganisms because metals cannot be degraded and thus accumulate in cells, disrupting disrupt cell metabolism [119]. An in-depth understanding of the effect of toxic metals on anammox activities would facilitate the application of anammox for the removal of nitrogen from these kinds of wastewater. The commonly investigated toxic metals in anammox systems are $\mathrm{Cu}, \mathrm{Zn}, \mathrm{Hg}, \mathrm{Cd}, \mathrm{Ag}$, and $\mathrm{Pb}$.

\subsubsection{Copper}

$\mathrm{Cu}$ is one of the essential elements to living organisms at micro concentrations, but it becomes very toxic at high concentrations. The toxic effect of $\mathrm{Cu}$ on microorganisms has been attributed to the soluble form of $\mathrm{Cu}$, which is typically found as $\mathrm{Cu}$ (II). The inhibitory effect of $\mathrm{Cu}$ (II) on anammox has been investigated in many studies [28,119-124] (Table 7). The toxic concentration of $\mathrm{Cu}$ (II) on anammox bacteria was determined to be quite low, and varied from 1.9 to $19.3 \mathrm{mg} / \mathrm{L}$. Anammox bacterial activity was found to decrease by $50 \%$ upon exposure to $\mathrm{Cu}$ (II) concentrations of $1.9 \mathrm{mg} / \mathrm{L}$ [28] and $4.2 \mathrm{mg} / \mathrm{L}$ [124] in a batch test using serum bottles. At a slightly higher concentration of Cu (II) ( $5 \mathrm{mg} / \mathrm{L}$ ), anammox activity was observed to decrease by more than $10 \%$ in the continuous feeding mode of a $500 \mathrm{~mL}$ reactor dominated by Planctomycetes [123]. However, in the same continuous mode in a $2.7 \mathrm{~L}$ reactor inoculated with anammox sludge from a 1 year operating reactor, anammox activity was not significantly inhibited when the influent wastewater contained $5.95 \mathrm{mg} / \mathrm{L}$ of $\mathrm{Cu}$ (II) [121]. In the same study, when the influent $\mathrm{Cu}$ (II) level increased to $12.6 \mathrm{mg} / \mathrm{L}$, a clear inhibition of anammox activity was recorded. The inhibition level of $\mathrm{Cu}$ (II) in the continuous mode seemed to be higher than that in the batch mode, which was similar to the toxic effect of nitrite. However, this was not true for the inhibition of $\mathrm{Cu}$ (II) on anammox activity because for a $\mathrm{Cu}$ (II) level of up to $16.3 \mathrm{mg} / \mathrm{L}$ in a batch test using serum bottles, anammox activity was only $20.1 \%$ [120]. The $\mathrm{IC}_{50}$ of $\mathrm{Cu}$ (II) in two other studies was $12.6 \mathrm{mg} / \mathrm{L}$ [122] and $19.3 \mathrm{mg} / \mathrm{L}$ [119]. Therefore, it can be said that the inhibition level of $\mathrm{Cu}(\mathrm{II})$ on anammox activity might generally depend on the seeding source. 
Table 7. Effect of toxic metals on anammox performance.

\begin{tabular}{|c|c|c|c|c|c|}
\hline Seeding Sources & Reactor & $\begin{array}{l}\text { Operation } \\
\text { Mode }\end{array}$ & $\begin{array}{l}\text { Toxic Metals and } \\
\text { Concentration } \\
(\mathrm{mg} / \mathrm{L})\end{array}$ & Effect & Ref. \\
\hline $\begin{array}{l}\text { Anammox sludge } \\
\text { dominated by KSU-1 } \\
\text { strain }\end{array}$ & $\begin{array}{l}120 \text { mL serum } \\
\text { vials }\end{array}$ & Batch test & $\begin{array}{l}\text { Cd: } 11.16 \\
\text { Ag: } 11.52 \\
\text { Hg: } 60.35 \\
\text { Pb: } 40\end{array}$ & $\begin{array}{c}\text { Inhibition by } 50 \% \\
\text { Inhibition by } 50 \% \\
\text { Inhibition by } 50 \% \\
\text { Activity decreased by } 7.19 \%\end{array}$ & [128] \\
\hline $\begin{array}{l}\text { Anammox sludge } \\
\text { dominated by } \\
\text { "Candidatus Kuenenia } \\
\text { stuttgartiensis" }\end{array}$ & $\begin{array}{l}160 \mathrm{~mL} \text { serum } \\
\text { flask }\end{array}$ & Batch test & $\begin{array}{l}\text { Cu: } 16.3 \\
\text { Zn: } 20.0\end{array}$ & Activity decreased by $20.1 \%$ & [120] \\
\hline $\begin{array}{l}\text { Non-acclimated } \\
\text { microbial sludge }\end{array}$ & Serum bottles & Batch test & Zn: 6.9 & Inhibition by $50 \%$ & [125] \\
\hline $\begin{array}{l}\text { Acclimated microbial } \\
\text { sludge }\end{array}$ & $\begin{array}{l}\text { Stirring SBBR } \\
\quad(2.5 \mathrm{~L})\end{array}$ & Continuous & $\mathrm{Zn}:<10$ & $\begin{array}{l}\text { Stimulated anammox } \\
\text { performance }\end{array}$ & [125] \\
\hline $\begin{array}{l}\text { Anammox sludge from } \\
\text { 1-year operating reactor }\end{array}$ & $2.7 \mathrm{~L}$ reactor & Continuous & $\begin{array}{l}\mathrm{Cu}: 5.95 \\
\mathrm{Cu}: 12.6\end{array}$ & $\begin{array}{l}\text { No significant inhibition } \\
\text { Clear inhibition }\end{array}$ & [121] \\
\hline $\begin{array}{l}\text { Anammox granular } \\
\text { sludge }\end{array}$ & $\begin{array}{l}1 \text { L UASB } \\
\text { reactors }\end{array}$ & Batch test & Cu: 12.6 & Inhibition by $50 \%$ & [122] \\
\hline $\begin{array}{l}\text { granular anammox } \\
\text { biomass }\end{array}$ & $\begin{array}{l}340 \text { mL serum } \\
\text { bottles }\end{array}$ & Batch test & $\begin{array}{l}\text { Cu: } 1.9 \\
\text { Zn: } 3.9\end{array}$ & $\begin{array}{l}\text { Inhibition by } 50 \% \\
\text { Inhibition by } 50 \%\end{array}$ & [28] \\
\hline $\begin{array}{l}\text { Anammox sludge } \\
\text { dominated by } \\
\text { "Candidatus" and } \\
\text { Planctomycetes }\end{array}$ & $500 \mathrm{~mL}$ reactor & $\begin{array}{l}\text { Continuous } \\
\text { feeding }\end{array}$ & $\begin{array}{l}\text { Ni: } 5 \\
\text { Cu: } 5 \\
\text { Co: } 5 \\
\text { Zn: } 10 \\
\text { Mo: } 0.2 \\
\end{array}$ & $\begin{array}{c}\text { Anammox activity decreased } \\
\text { by more than } 10 \%\end{array}$ & [123] \\
\hline $\begin{array}{l}\text { Anammox sludge } \\
\text { dominated by } \\
\text { "Candidatus Brocadia" }\end{array}$ & $\begin{array}{l}120 \text { mL serum } \\
\text { bottle }\end{array}$ & Batch test & $\begin{array}{l}\text { Cd: } 7.00 \\
\mathrm{Hg}: 2.33 \\
\mathrm{~Pb}: 10.40 \\
\mathrm{Cr}: 9.84 \\
\text { As: } 60\end{array}$ & $\begin{array}{c}\text { Inhibition by } 50 \% \\
\text { Inhibition by } 50 \% \\
\text { Inhibition by } 50 \% \\
\text { Inhibition by } 50 \% \\
\text { Activity decreased by } 29.67 \% \\
\end{array}$ & [129] \\
\hline $\begin{array}{l}\text { Granular anammox } \\
\text { biomass }\end{array}$ & $\begin{array}{l}160 \text { mL serum } \\
\text { bottles }\end{array}$ & Batch test & $\begin{array}{l}\text { Cu: } 4.2 \\
\text { Zn: } 7.6 \\
\text { Cd: } 11.2 \\
\text { Ni: } 48.6 \\
\text { Mo: } 22.7 \\
\text { Pb: } 6.0\end{array}$ & $\begin{array}{l}\text { Inhibition by } 50 \% \\
\text { Inhibition by } 50 \% \\
\text { Inhibition by } 50 \% \\
\text { Inhibition by } 50 \% \\
\text { Moderately inhibitory } \\
\text { Moderately inhibitory } \\
\end{array}$ & [124] \\
\hline $\begin{array}{l}\text { Anammox granular } \\
\text { sludge }\end{array}$ & $\begin{array}{l}1 \text { L UASB } \\
\text { reactor }\end{array}$ & Continuous & Zn: 25 & Inhibition by $50 \%$ & [126] \\
\hline $\begin{array}{l}\text { Anammox sludge and } \\
\text { nitrification sludge }\end{array}$ & $\begin{array}{c}\text { Anammox } \\
\text { biofilter reactor }\end{array}$ & Continuous & Zn: 20 & Irreversible inhibition & [127] \\
\hline $\begin{array}{c}\text { Granular sludge } \\
\text { dominated by Brocadia } \\
\text { fulgida }\end{array}$ & $25 \mathrm{~mL}$ vials & Batch test & $\begin{array}{c}\text { Cu: } 19.3 \\
\text { Cr: } 26.9 \\
\text { Pb: } 45.6 \\
\text { Zn: } 59.1 \\
\text { Ni: } 69.2 \\
\text { Cd: } 174.6 \\
\text { Mn: } 175.8\end{array}$ & Inhibition by $50 \%$ & [119] \\
\hline
\end{tabular}

\subsubsection{Zinc}

In addition to $\mathrm{Cu}(\mathrm{II})$, the other metal commonly investigated in anammox studies is $\mathrm{Zn}$ (II). The toxicity of $\mathrm{Zn}(\mathrm{II})$ towards anammox bacteria appears to be less than that of $\mathrm{Cu}$ (II) because the inhibition concentration of $\mathrm{Zn}$ (II) has been reported to be higher $(3.9-59.1 \mathrm{mg} / \mathrm{L})$ than that of $\mathrm{Cu}(\mathrm{II})$ (Table 7). The $\mathrm{IC}_{50}$ value was determined from several batch tests using serum bottles as $3.9 \mathrm{mg} / \mathrm{L}$ [28], $6.9 \mathrm{mg} / \mathrm{L}$ [125], and $7.6 \mathrm{mg} / \mathrm{L}$ [124]. In the continuous mode operation with a bigger reactor, this value was recorded at $25 \mathrm{mg} / \mathrm{L}$ [126], which is much higher than those of the batch tests. In addition, the inhibition of $\mathrm{Zn}$ (II) on an anammox sludge and nitrification sludge in an anammox biofilter reactor was found to be irreversible when $\mathrm{Zn}$ (II) concentration was increased to $20 \mathrm{mg} / \mathrm{L}$ [127]. The activity of anammox sludge dominated by Planctomycetes was decreased by more than $10 \%$ in a $500 \mathrm{~mL}$ reactor 
fed with continuous influent containing $10 \mathrm{mg} / \mathrm{L}$ of $\mathrm{Zn}$ (II) [123]. A decrease of $20.1 \%$ in the activity of anammox sludge dominated by "Candidatus Kuenenia stuttgartiensis" was observed in a batch test with $160 \mathrm{~mL}$ serum flasks [120]. In contrast to these observations, anammox performance was found to be stimulated in the continuous operation of a stirring $2.5 \mathrm{~L} \mathrm{SBBR}$ with acclimated microbial sludge [125]. In particular, the $\mathrm{IC}_{50}$ value of $\mathrm{Zn}$ (II) for granular sludge dominated by " $\mathrm{C}$. Brocadia fulgida" was extremely high $(59.1 \mathrm{mg} / \mathrm{L})$ [119].

\subsubsection{Cadmium}

$\mathrm{Cd}$ is a biologically toxic metal with well-recognized adverse effects on most human organs. $\mathrm{Cd}$ (II) occurs in wastewater owing to the increasing use of cadmium in modern industry. Currently, the inhibitory effect of $\mathrm{Cd}(\mathrm{II})$ on anammox bacteria has only been investigated at a batch scale. In a batch test using 120-mL serum bottles, the performance of anammox sludge dominated by "Candidatus Brocadia" was found to be decreased by $50 \%$ at a Cd(II) concentration of $7 \mathrm{mg} / \mathrm{L}$ [129]. Similarly, the $\mathrm{IC}_{50}$ values of Cd(II) for anammox bacteria in other batch tests were $11.16 \mathrm{mg} / \mathrm{L} \mathrm{[128]} \mathrm{and} 11.2 \mathrm{mg} / \mathrm{L} \mathrm{[124].}$ The highest $\mathrm{IC}_{50}$ of $\mathrm{Cd}(\mathrm{II})(174.6 \mathrm{mg} / \mathrm{L})$ was found with granular sludge dominated by " $\mathrm{C}$. Brocadia fulgida" [119].

\subsubsection{Lead}

Similar to $\mathrm{Cd}(\mathrm{II})$, the toxic effect of $\mathrm{Pb}$ (II) has only been investigated in batch tests using serum bottles. The $\mathrm{IC}_{50}$ of $\mathrm{Pb}$ (II) was determined differently in studies using different anammox sludges. $\mathrm{The} \mathrm{Pb}$ (II) concentration of $10.4 \mathrm{mg} / \mathrm{L}$ decreased the activity of anammox sludge dominated by "Candidatus Brocadia" up to 50\% [129], whereas this level of reduction in inhibition was found at $\mathrm{Pb}$ (II) concentration of $45.6 \mathrm{mg} / \mathrm{L}$ in a $25 \mathrm{~mL}$ vial test using granular sludge dominated by "Candidatus Brocadia fulgida" [119]. However, the activity of anammox sludge dominated by the KSU-1 strain decreased by only $7.19 \%$ upon exposure to $\mathrm{Pb}$ (II) concentration of $40 \mathrm{mg} / \mathrm{L}$ [128]. In addition, the toxic effect of $\mathrm{Pb}$ (II) was said to be moderately inhibitory in a batch test with granular anammox biomass at a $\mathrm{Pb}(\mathrm{II})$ concentration of $6 \mathrm{mg} / \mathrm{L}$ [124].

\subsubsection{Nickel}

$\mathrm{Ni}$ is one of the microelements that is recognized to be essential to organisms at very low levels. However, it becomes highly toxic with chronic exposure at high levels [130]. The toxic effect of $\mathrm{Ni}(\mathrm{II})$ on anammox activity has not been as extensively investigated as that of the other toxic metals listed thus far. However, the current literature provides data regarding $\mathrm{Ni}$ (II) inhibition in both continuous mode and batch operations $[119,123,124]$. In the continuous feeding of a $500 \mathrm{~mL}$ reactor, anammox activity decreased by $10 \%$ upon exposure to an $\mathrm{Ni}$ (II) concentration of $5 \mathrm{mg} / \mathrm{L}$ [123]. The $\mathrm{IC}_{50}$ values of $\mathrm{Ni}(\mathrm{II})$ in the batch test of $160 \mathrm{~mL}$ serum bottles and $25 \mathrm{~mL}$ vials were $48.6 \mathrm{mg} / \mathrm{L}$ [124] and $69.2 \mathrm{mg} / \mathrm{L}$ [119], respectively.

\subsubsection{Other Toxic Metals}

Other toxic metals such as $\mathrm{Hg}, \mathrm{Mo}, \mathrm{Cr}, \mathrm{Ag}, \mathrm{Co}$, and As have been investigated in several studies operating at batch or continuous feeding modes. $\mathrm{The}^{\mathrm{IC}} \mathrm{C}_{50}$ of $\mathrm{Hg}$ (II) for anammox sludge dominated by the KSU-1 strain was $60.35 \mathrm{mg} / \mathrm{L}$ [128], which is significantly different from that for anammox sludge dominated by "Candidatus Brocadia" (2.33 mg/L) [129] with the same reactor volume and operation mode. Mo was found to be moderately inhibitory to anammox activity at a level of $22.7 \mathrm{mg} / \mathrm{L}$ in a batch test [124], whereas in another study with continuous feeding, $0.2 \mathrm{mg} / \mathrm{L}$ of Mo could decrease anammox activity by more than $10 \%$ [123]. The $\mathrm{IC}_{50}$ values of $\mathrm{Cr}(\mathrm{VI})$ were $9.84 \mathrm{mg} / \mathrm{L}$ for a batch test using $120 \mathrm{~mL}$ serum bottles [129] and $26.9 \mathrm{mg} / \mathrm{L}$ for a batch test using $25 \mathrm{~mL}$ vials [119]. As a well-known antibacterial agent, $\mathrm{Ag}(\mathrm{I})$ could decrease anammox activity by up to $50 \%$ at an exposure level of $11.52 \mathrm{mg} / \mathrm{L}$ [128]. A Co(II) concentration of $5 \mathrm{mg} / \mathrm{L}$ could decrease anammox activity by more than $10 \%$ in the continuous feeding mode of a $500 \mathrm{~mL}$ reactor. $\mathrm{As}(\mathrm{III})$, which is more toxic than $\mathrm{As}(\mathrm{V})$, 
was investigated for its inhibitory effect on anammox sludge dominated by "Candidatus Brocadia" [129]. The activity of anammox bacteria was decreased by $29.67 \%$ upon exposure to an As(III) concentration of $60 \mathrm{mg} / \mathrm{L}$ [129]. Mn is known to be a less toxic metal; $\mathrm{IC}_{50}$ of $\mathrm{Mn}(\mathrm{II})$ was $175 \mathrm{mg} / \mathrm{L}$ in a batch test with $25 \mathrm{~mL}$ vials [119].

\subsection{Inhibition by Toxic Organic Compounds}

Organic compounds occurring in wastewater are usually divided into two groups, non-toxic organic compounds and toxic organic compounds. Non-toxic organic compounds can serve as a carbon source for microorganisms. However, most anammox bacteria are chemoautotrophic microorganisms that utilize inorganic carbon such as $\mathrm{CO}_{2}, \mathrm{CO}_{3}{ }^{2-}$, and $\mathrm{HCO}_{3}{ }^{-}$as the only carbon source [131]. Therefore, the presence of non-toxic organic compounds at high levels can cause an adverse effect on the anammox system because heterotrophic bacteria grow on organic carbon and compete with the anammox bacteria [99]. In cases where anammox bacteria might consume organic carbon, they would use these as a substrate, rather than ammonium and nitrite, in the presence of high concentrations of organic carbon. These reasons contribute to the negative effect of high organic content on anammox systems. This review focuses more on the toxic organic compounds which commonly occur in wastewater.

\subsubsection{Alcohols}

Alcohol, especially ethanol, is commonly used as a disinfectant and sanitizing agent. The inhibitory effect of alcohol on anammox activity has been investigated previously [47,70,132-134]. During the initial stage of anammox enrichment from anaerobic sludge, the alcohol fermentation from organic matter can occur simultaneously because anammox is an anaerobic system. Methanol is the most toxic compound among alcohols because it can be converted to formaldehyde inside the cell and destroy cell metabolism [135]. It has been reported that in marine sediment, methanol can completely inhibit the anammox process at a concentration of $96-128 \mathrm{mg} / \mathrm{L}$, because at this concentration, the denitrification process was stimulated [132]. In another study [133], methanol was considered to be the most toxic inhibitor, causing a complete and irreversible inhibition of anammox activity at a methanol concentration as low as $16 \mathrm{mg} / \mathrm{L}$. However, the anammox activity in a batch test was found to be decreased by $71 \%$ in the presence of $160 \mathrm{mg} / \mathrm{L}$ methanol [47], whereas the addition of $1 \mathrm{mM}$ methanol decreased anammox activity by up to $86 \%$ [134]. The difference in methanol resistance in the anammox process could be attributed to the difference in anammox species of microbial communities. Methanol-resistant anammox was successfully enriched from methanogenesis sludge [136]. This methanol-resistant anammox sludge was dominated by "Candidatus Brocadia".

\subsubsection{Phenol}

Phenol and phenolic compounds are not commonly found in domestic wastewater but are present in industrial wastewater from chemical industries, petroleum refineries, coal conversion, and fiberboard manufacturing [137-139]. A highly phenol-resistant anammox consortium was successfully enriched through a long adaptation process for treating wastewater from coke-ovens [140]. Anammox activity decreased when phenol concentration increased from 50 to $550 \mathrm{mg} / \mathrm{L}$, but gradually recovered after a period of acclimation and even improved after being adapted. In the presence of other inhibitory agents such as sulfide and $\mathrm{Cu}(\mathrm{II})$, the toxic effect of phenol was generally synergistic [118]. In fact, the cooperative inhibition of phenol and $\mathrm{Cu}(\mathrm{III})$ was synergistic at a low phenol concentration of $75 \mathrm{mg} / \mathrm{L}$, whereas it was antagonistic at a high phenol concentration of $300 \mathrm{mg} / \mathrm{L} \mathrm{[118].} \mathrm{The} \mathrm{inhibitory} \mathrm{effect} \mathrm{of}$ phenol was also found to be synergistic with that of thiocyanate [141]. Anammox activity decreased by more than $90 \%$ upon short-term exposure to a $100 \mathrm{mg} / \mathrm{L}$ phenol and thiocyanate mixture. Recently, more studies have focused on the inhibitory effect on anammox by phenol and have reported that the inhibition of anammox activity by phenol was restorable. Anammox performance was significantly suppressed upon exposure to phenol concentrations of $12.5-50 \mathrm{mg} / \mathrm{L}$ for nearly 200 days [142]. However, when phenol was depleted from the influent, the anammox performance recovered after $81 \mathrm{~d}$. It was 
interesting that the recovery model with phenol as an inhibitor was very different from the test for sulfide as the inhibitor. In another study [143], an influent containing $50 \mathrm{mg} / \mathrm{L}$ of phenol could significantly depress the anammox performance of 1 L UASB reactors seeded with anammox granular sludge. The $\mathrm{IC}_{50}$ value of phenol was also defined at $678.2 \mathrm{mg} / \mathrm{L}$ in a batch test under the same conditions. The granule characteristics and stoichiometric ratios of anammox were observed to be changed under the stress of phenol. In depth, the presence of phenol changed the microbial community considerably in an SBR anammox system [144]. The anammox bacterial population was reduced from $14.7 \%$ to $10.1 \%$ and phenol-degrading bacteria were selectively enriched in the presence of phenol. The anammox bacterial community even shifted from "Candidatus Kuenenia stuttgartiensis" to "Candidatus Brocadia sinica" upon exposure to a mixture of phenol and thiocyanate at 16-32 mg/L over the long term of $262 \mathrm{~d}$ [141]. Phenol also exhibited an inhibitory effect on partial nitritation activity

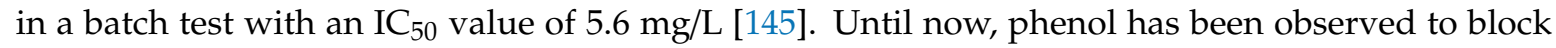
the synthesis of hydrazine as the key enzyme in anammoxosomes, which is the main mechanism for immediate inhibition of anammox activity [146].

Other phenolic compounds have also been revealed to have an inhibitory effect on anammox activity similar to that of phenol. It was reported that 2,4-dinitrophenol concentrations of 37 and $15 \mathrm{mg} / \mathrm{L}$ partially inhibited the anammox activity of biomass-enriched municipal sludge [147]. In another study [148], the addition of $37 \mathrm{mg} / \mathrm{L} \mathrm{2,4-dinitrophenol} \mathrm{decreased} \mathrm{anammox} \mathrm{activity} \mathrm{by} \mathrm{up} \mathrm{to} \mathrm{53 \% ,} \mathrm{and}$ anammox activity was completely inhibited when 2,4-dinitrophenol concentration was increased to $368 \mathrm{mg} / \mathrm{L}$. The effect of phenolic compounds on anammox activity was dependent on the types of phenolic compounds [149]. Previous investigation with anammox granules dominated by Brocadia sp. indicated that $o$-cresol and $o$-chlorophenol resulted in a toxic effect to anammox bacteria. Anammox performance did not recover after bacterial granules were washed from $o$-cresol and $o$-chlorophenol, whereas the presence of $p$-nitrophenol and quinoline exhibited an inhibitory effect on anammox activity. When anammox granules were washed from $p$-nitrophenol and quinoline, specific anammox activity was almost recovered to the initial stage without inhibitors. Exposure of the anammox granules to a higher concentration of phenolic compounds would result in a higher reduction in anammox activity [149]. The joint effect of $o$-cresol, $o$-chlorophenol, $p$-nitrophenol, and quinoline was determined to be synergistic.

\subsubsection{Antibiotics}

Antibiotics are widely applied in humans, animals, and fisheries to treat infection and especially used in aquaculture and breeding farms as prophylaxis. Therefore, antibiotics are typically detected in various livestock wastewaters [150]. Owing to their ubiquitous migration, antibiotics are now found in all aquatic environments at various levels [151]. A thorough understanding on the effect of antibiotics on anammox performance is required. Currently, a wide range of antibiotics such as penicillin, chloramphenicol, ampicillin, tetracycline, sulfathiazole, oxytetracycline, amoxicillin, florfenicol, sulfamethazine, and oxytetracycline were the most investigated antibiotics for the anammox system (Table 8).

Antibiotics have a strong negative effect on anammox activity. Higher antibiotic concentrations resulted in lower nitrogen removal in an anammox system [148]. Anammox activity decreased by $17 \%$ in the presence of $1 \mathrm{mg} / \mathrm{L}$ penicillin and decreased to $36 \%$ when penicillin concentration increased to $100 \mathrm{mg} / \mathrm{L}$. More than $90 \%$ of anammox activity was inhibited by $200 \mathrm{mg} / \mathrm{L}$ chloramphenicol or $800 \mathrm{mg} / \mathrm{L}$ ampicillin. Chloramphenicol of $200 \mathrm{~g} / \mathrm{L}$ could decrease anammox activity by $98 \%$ for the first $3 \mathrm{~d}$ of exposure; however, anammox activity was slightly improved after $3 \mathrm{~d}$ of incubation owing to acclimation [148]. Similarly, anammox activity was decreased by $20 \%$ to $80 \%$ in a batch test using $25 \mathrm{~mL}$ serum vials with tetracycline hydrochloride at 100-1000 mg/L or chloramphenicol at 250-1000 mg/L [152]. However, low concentration of antibiotics such as allylthiourea and chloramphenicol did not show a meaningful inhibition on anammox activity [26]. Allylthiourea of $1 \mathrm{mg} / \mathrm{L}$ decreased anammox activity by more than $20 \%$, whereas chloramphenicol of $1 \mathrm{mg} / \mathrm{L}$ did not result in any inhibition. 
The level of toxicity of antibiotics on anammox bacteria also depended on the type of antibiotics. The $\mathrm{IC}_{50}$ value of sulfathiazole in a batch test using $200 \mathrm{~mL}$ vials was found to be $650 \mathrm{mg} / \mathrm{L}$, whereas this value for oxytetracycline was determined to be $1100 \mathrm{mg} / \mathrm{L}$ [28]. In a continuous operation of anammox dominated by "Candidatus Kuenenia stuttgartiensis", florfenicol at $20 \mathrm{mg} / \mathrm{L}$ could decrease anammox activity by up to 50\% [153]. Amoxicillin at $150 \mathrm{mg} / \mathrm{L}$ showed a severe inhibition, whereas sulfamethazine at $200 \mathrm{mg} / \mathrm{L}$ only exhibited a slight inhibition on anammox activity of the same anammox granules.

Table 8. Effect of antibiotics on anammox performance.

\begin{tabular}{|c|c|c|c|c|c|}
\hline Seeding Sources & Reactor & $\begin{array}{l}\text { Operation } \\
\text { Mode }\end{array}$ & $\begin{array}{c}\text { Antibiotics and } \\
\text { Concentration (mg/L) }\end{array}$ & Effect & Ref. \\
\hline $\begin{array}{l}\text { Sludge from the } \\
\text { denitrifying } \\
\text { fluidized bed } \\
\text { reactor }\end{array}$ & $\begin{array}{l}500 \mathrm{~mL} \\
\text { serum } \\
\text { bottle }\end{array}$ & Batch test & $\begin{array}{c}\text { Penicillin: } 1 \\
\text { Penicillin: } 100 \\
\text { Chloramphenicol: } 20 \\
\text { Chloramphenicol: } 200 \\
\text { Ampicillin: } 400 \\
\text { Ampicillin: } 800\end{array}$ & $\begin{array}{l}\text { Activity decreased by } 17 \% \\
\text { Activity decreased by } 36 \% \\
\text { Activity decreased by } 36 \% \\
\text { Activity decreased by } 98 \% \\
\text { for first } 3 \mathrm{~d} \text { and } 68 \% \text { after } 3 \mathrm{~d} \\
\text { Activity decreased by } 71 \% \\
\text { Activity decreased by } 94 \%\end{array}$ & [148] \\
\hline $\begin{array}{c}\text { Granular Anammox } \\
\text { sludge }\end{array}$ & $\begin{array}{c}25 \mathrm{~mL} \\
\text { serum vials }\end{array}$ & Batch test & $\begin{array}{l}\text { Tetracycline } \\
\text { hydrochloride: } \\
\text { 100-1000 } \\
\text { Chloramphenicol: } \\
\text { 250-1000 }\end{array}$ & $\begin{array}{c}\text { Activity decreased from } 20 \% \\
\text { to } 80 \% \\
\text { Activity decreased from } 20 \% \\
\text { to } 80 \%\end{array}$ & [152] \\
\hline $\begin{array}{c}\text { Granular Anammox } \\
\text { sludge }\end{array}$ & $\begin{array}{l}1 \mathrm{~L} \mathrm{SBR} \\
\text { reactor }\end{array}$ & Continuous & $\begin{array}{c}\text { Tetracycline } \\
\text { hydrochloride: } 10 \\
\text { Chloramphenicol: } 20\end{array}$ & $\begin{array}{l}\text { Activity decreased by } 60 \% \\
\text { Activity decreased by } 80 \% \\
\text { after }\end{array}$ & [152] \\
\hline $\begin{array}{l}\text { Anammox biomass } \\
\text { dominated by } \\
\text { "Candidatus Kuenenia } \\
\text { stuttgartiensis" }\end{array}$ & $\begin{array}{c}25 \mathrm{~mL} \\
\text { serum vials }\end{array}$ & Batch test & $\begin{array}{c}\text { Allylthiourea: } 1 \\
\text { Chloramphenicol: } 1\end{array}$ & $\begin{array}{c}\text { Activity decreased by more } \\
\text { than } 20 \% \\
\text { - No inhibition }\end{array}$ & [26] \\
\hline $\begin{array}{l}\text { Granular anammox } \\
\text { biomass }\end{array}$ & $\begin{array}{l}200 \mathrm{~mL} \\
\text { vials }\end{array}$ & Batch test & $\begin{array}{c}\text { Sulfathiazole: } 650 \\
\text { Oxytetracycline: } 1100\end{array}$ & $\begin{array}{l}\text { Inhibition by } 50 \% \\
\text { Inhibition by } 50 \%\end{array}$ & [28] \\
\hline $\begin{array}{l}\text { Anammox seed } \\
\text { granules dominated } \\
\text { by "Candidatus } \\
\text { Kuenenia } \\
\text { stuttgartiensis" }\end{array}$ & $\begin{array}{l}1 \text { L UASB } \\
\text { reactor }\end{array}$ & Continuous & $\begin{array}{l}\text { Amoxicillin: } 150 \\
\text { Florfenicol: } 20 \\
\text { Sulfamethazine: } 200\end{array}$ & $\begin{array}{l}\text { Severely inhibited } \\
\text { Inhibition by } 50 \% \\
\text { Slight inhibition }\end{array}$ & [153] \\
\hline $\begin{array}{l}\text { Anammox seed } \\
\text { granules dominated } \\
\text { by "Candidatus } \\
\text { Kuenenia } \\
\text { stuttgartiensis" }\end{array}$ & $\begin{array}{l}1 \text { L UASB } \\
\text { reactor }\end{array}$ & Continuous & Oxytetracycline: 2 & $\begin{array}{l}\text { Specific anammox activity } \\
\text { decreased by } 81.3 \%\end{array}$ & [154] \\
\hline $\begin{array}{l}\text { Anammox bacteria } \\
\text { from an SBR }\end{array}$ & $\begin{array}{l}1 \text { L serum } \\
\text { bottle }\end{array}$ & Batch test & $\begin{array}{c}\text { Oxytetracycline: } \\
10-100\end{array}$ & Complete inhibition & [155] \\
\hline $\begin{array}{l}\text { Anammox mixed } \\
\text { culture from UASB } \\
\text { reactor }\end{array}$ & $\begin{array}{l}160 \mathrm{~mL} \\
\text { serum } \\
\text { bottle }\end{array}$ & Batch test & Oxytetracycline: 517.5 & Inhibition by $50 \%$ & [156] \\
\hline $\begin{array}{l}\text { Anammox mixed } \\
\text { culture from UASB } \\
\text { reactor }\end{array}$ & 1 L UASB & Continuous & Oxytetracycline: 50 & Activity loss of $90.4 \%$ & [156] \\
\hline
\end{tabular}

The inhibitory effect of the same antibiotic compound can differ with different anammox seeding sources and operation conditions. The $\mathrm{IC}_{50}$ of oxytetracycline in a batch test with an anammox mixed culture from an UASB reactor was found to be $517.5 \mathrm{mg} / \mathrm{L}$ [156]. However, complete inhibition of anammox activity was observed with oxytetracycline concentrations from 10 to $100 \mathrm{mg} / \mathrm{L}$ in a $1 \mathrm{~L}$ serum bottle test [155]. The toxic concentration of oxytetracycline seems to be lower in the continuous operation. A continuous influent with $2 \mathrm{mg} / \mathrm{L}$ oxytetracycline in a $1 \mathrm{~L}$ UASB reactor decreased specific anammox activity by $81.3 \%$ [154]. In another continuous-mode study [156], an anammox activity loss of $90.4 \%$ was observed with $50 \mathrm{mg} / \mathrm{L}$ oxytetracycline. In a $1 \mathrm{~L} \mathrm{SBR}$ reactor inoculated with granular 
anammox sludge operated in continuous mode, $10 \mathrm{mg} / \mathrm{L}$ tetracycline hydrochloride and $20 \mathrm{mg} / \mathrm{L}$ chloramphenicol decreased anammox activities by $60 \%$ and $80 \%$, respectively [152].

The toxic effect of antibiotics was also investigated in the presence of other inhibitors. The cooperative toxicity of oxytetracycline and $\mathrm{Cu}$ (II) on the anammox granular sludge from an UASB reactor was observed to be antagonistic, whereas the combination effect of oxytetracycline and sulfide was generally synergistic [118]. The toxic effect of an oxytetracycline and $\mathrm{Cu}$ (II) mixture was always smaller than that of the individual compounds. At a low $\mathrm{Cu}$ (II) concentration, the toxic effects of the mixture decreased with the increase in oxytetracycline concentration, indicating that the addition of oxytetracycline weakened the toxic effect of $\mathrm{Cu}$ (II) on anammox bacteria. In a study seeking to acclimatize anammox bacteria with oxytetracycline, it was found that anammox bacteria can resist the toxicity of oxytetracycline via the efflux pumping mechanism [154]. In addition, anammox performance was totally recovered after $2 \mathrm{mg} / \mathrm{L}$ of oxytetracycline was withdrawn completely from the reactor. The feasibility of anammox application for treating antibiotic-containing wastewater has also been indicated previously [153]. After long-term acclimatization, anammox sludge dominated by "Candidatus Kuenenia stuttgartiensis" can achieve a resistance to $60 \mathrm{mg} / \mathrm{L}$ amoxicillin, $10 \mathrm{mg} / \mathrm{L}$ florfenicol, and $100 \mathrm{mg} / \mathrm{L}$ sulfamethazine.

\subsection{Inhibition by Salinity}

Saline solution creates high osmotic pressure that can kill bacteria owing to water loss from cells [157]. Therefore, high-salinity wastewater might not be treatable by any biological system. High-salinity wastewater is usually generated from food waste leachate, seafood processing industries, textile dyeing, and tanneries [158]. However, the anammox process could be a potential candidate for these high-salinity wastewaters because the anammox reaction has also been detected in marine environments [158]. Recently, it was reported that fresh anammox sludge can also be resistant to high salinity and perform stably under extreme high salt concentration after a long-term acclimation [159-161] (Table 9).

Table 9. Effect of salinity on anammox performance.

\begin{tabular}{|c|c|c|c|c|c|}
\hline Seeding Sources & Reactor & $\begin{array}{l}\text { Operation } \\
\text { Mode }\end{array}$ & $\begin{array}{c}\text { Salts and } \\
\text { Concentration }(\mathrm{g} / \mathrm{L})\end{array}$ & Effect & Ref. \\
\hline $\begin{array}{l}\text { Anammox sludge } \\
\text { from an SBR }\end{array}$ & $2 \mathrm{~L} \mathrm{SBR}$ & Batch & $\mathrm{NaCl}: 5-10$ & $\begin{array}{l}\text { Improved biomass retention } \\
\text { Anammox activity slightly reduced } \\
\text { initially but gradually increases }\end{array}$ & [161] \\
\hline $\begin{array}{l}\text { Mature anammox } \\
\text { sludge }\end{array}$ & $3 \mathrm{~L} \mathrm{SBR}$ & Continuous & $\mathrm{NaCl}: 0-30$ & $\begin{array}{c}\text { Enhanced the aggregation of } \\
\text { anammox biomass } \\
\text { Stimulated the activity at } \\
\text { concentrations of } 6-15 \mathrm{~g} / \mathrm{L} \\
\text { Activity decreased at concentrations } \\
\text { higher than } 15 \mathrm{~g} / \mathrm{L}\end{array}$ & [162] \\
\hline Anammox sludge & $\begin{array}{l}50 \text { L lab-scale } \\
\text { RBC }\end{array}$ & Batch test & $\begin{array}{c}\mathrm{NaCl}: 6 \\
\mathrm{NaCl}: 30 \text { (shock load) }\end{array}$ & $\begin{array}{l}\text { No significant effect } \\
96 \% \text { loss in anammox activity for } \\
\text { non-adapted biomass } \\
58 \% \text { loss in anammox activity for } \\
\text { adapted biomass }\end{array}$ & [163] \\
\hline $\begin{array}{l}\text { Anammox sludge } \\
\text { dominated by } \\
\text { "Candidatus Kuenenia } \\
\text { stuttgartiensis" }\end{array}$ & $25 \mathrm{~mL}$ vials & Batch test & $\begin{array}{c}\mathrm{NaCl}: 13.45 \\
\mathrm{Na}_{2} \mathrm{SO}_{4}: 11.36 \\
\mathrm{KCl}: 14.9\end{array}$ & $\begin{array}{l}\text { Inhibition by } 50 \% \\
\text { Inhibition by } 50 \% \\
\text { Inhibition by } 50 \%\end{array}$ & {$[26]$} \\
\hline $\begin{array}{l}\text { Anaerobic activated } \\
\text { sludge }\end{array}$ & $\begin{array}{l}5 \text { L UASB } \\
\text { bioreactor }\end{array}$ & Batch test & $\mathrm{NaCl}: 30$ (shock load) & $\begin{array}{l}\text { Activity decreased by } 67.5 \% \text { for } \\
\text { non-adapted biomass } \\
\text { Activity decreased by } 45.1 \% \text { for } \\
\text { adapted biomass }\end{array}$ & {$[164]$} \\
\hline $\begin{array}{l}\text { Freshwater } \\
\text { anammox sludge }\end{array}$ & $\begin{array}{l}2.8 \mathrm{~L} \text { up-flow } \\
\text { fixed- } \\
\text { bed column } \\
\text { reactor }\end{array}$ & Continuous & $\begin{array}{c}\mathrm{NaCl}: 30 \\
\mathrm{NaCl}:>30\end{array}$ & $\begin{array}{l}\text { Stable nitrogen removal rate } \\
\text { Nitrogen removal sharply declined }\end{array}$ & [165] \\
\hline
\end{tabular}


Table 9. Cont.

\begin{tabular}{|c|c|c|c|c|c|}
\hline Seeding Sources & Reactor & $\begin{array}{l}\text { Operation } \\
\text { Mode }\end{array}$ & $\begin{array}{c}\text { Salts and } \\
\text { Concentration }(\mathrm{g} / \mathrm{L})\end{array}$ & Effect & Ref. \\
\hline $\begin{array}{c}\text { Anammox bacterium } \\
\text { KU2 }\end{array}$ & $\begin{array}{c}7 \mathrm{~L} \text { up-flow } \\
\text { column reactor } \\
\text { that }\end{array}$ & Continuous & $\mathrm{NaCl}: 30$ & $\begin{array}{l}\text { Stable nitrogen removal after a } \\
\text { period of adaptation }\end{array}$ & [67] \\
\hline Anammox sludge & $\begin{array}{l}2.5 \mathrm{~L} \mathrm{UASB} \\
\text { reactor }\end{array}$ & Continuous & $\mathrm{NaCl}: 5-60$ & $\begin{array}{l}\text { Sludge retention time decreased } \\
\text { with the increase in } \mathrm{NaCl} \text { load } \\
\text { Nitrogen removal rate decreased } \\
\text { significantly with } \mathrm{NaCl}>10 \mathrm{~g} / \mathrm{L}\end{array}$ & [166] \\
\hline $\begin{array}{c}\text { Marine anammox } \\
\text { bacteria dominated } \\
\text { by Planctomycete } \\
\text { UKU-1 }\end{array}$ & $\begin{array}{l}0.2 \mathrm{~L} \text { up-flow } \\
\text { column } \\
\text { reactor } \\
\text { containing }\end{array}$ & Continuous & $\mathrm{NaCl}: 0-75$ & $\begin{array}{l}\text { Stable nitrogen removal with } \mathrm{NaCl} \\
\quad<50 \mathrm{~g} / \mathrm{L} \\
\text { Activity significantly declined with } \\
\mathrm{NaCl} \text { of } 75 \mathrm{~g} / \mathrm{L}\end{array}$ & [167] \\
\hline $\begin{array}{l}\text { Anammox granule } \\
\text { dominated by } \\
\text { "Candidatus Brocadia } \\
\text { fulgida" }\end{array}$ & $10 \mathrm{~L} \mathrm{MBBR}$ & Continuous & NaCl: $0-15$ & Complete inhibition at $15 \mathrm{~g} / \mathrm{L}$ & [168] \\
\hline Anammox sludge & $\begin{array}{l}1 \mathrm{~L} \mathrm{UASB} \\
\text { reactor }\end{array}$ & Continuous & $\mathrm{NaCl}: 5-30$ & $\begin{array}{l}\text { Performance degraded at } \mathrm{NaCl} \\
\text { higher than } 15 \mathrm{~g} / \mathrm{L}\end{array}$ & [169] \\
\hline Anammox sludge & $1 \mathrm{~L} \mathrm{SBR}$ & Continuous & $\begin{array}{l}\mathrm{NaCl}: 5,15 \\
\mathrm{CaCl}_{2}: 5\end{array}$ & $\begin{array}{l}5 \mathrm{~g} / \mathrm{L} \text { of } \mathrm{NaCl} \text { and } \mathrm{CaCl}_{2} \text { favored the } \\
\text { formation of anammox biofilm } \\
\text { Inhibitory effect observed at } \mathrm{NaCl} \\
15 \mathrm{~g} / \mathrm{L}\end{array}$ & [170] \\
\hline $\begin{array}{l}\text { Anammox bacteria } \\
\text { from estuarine and } \\
\text { coastal wetlands }\end{array}$ & $12 \mathrm{~mL}$ vials & Batch test & NaCl: $0-40$ & $\begin{array}{c}\text { Maximal anammox activity at } \mathrm{NaCl} \\
5 \mathrm{~g} / \mathrm{L} \\
\text { Inhibition at } \mathrm{NaCl} \text { higher than } \\
30 \mathrm{~g} / \mathrm{L}\end{array}$ & [171] \\
\hline Anammox sludge & $\begin{array}{l}6 \mathrm{~L} \mathrm{UASB} \\
\text { reactor }\end{array}$ & Continuous & $\mathrm{NaCl}: 8-38$ & $\begin{array}{l}\text { Activity inhibition from shock load } \\
\text { of } 8-38 \mathrm{~g} / \mathrm{L} \mathrm{NaCl} \\
\text { Nitrogen removal decreased slightly } \\
\text { and stable at } \mathrm{NaCl} \text { range of } 8-18 \mathrm{~g} / \mathrm{L}\end{array}$ & [172] \\
\hline Anammox sludge & $\begin{array}{l}5 \mathrm{~L} \text { non-woven } \\
\text { biofilm reactors }\end{array}$ & Continuous & $\mathrm{NaCl}: 0-20$ & $\begin{array}{l}\text { Nitrogen removal deteriorated at } \\
\mathrm{NaCl} \text { higher than } 10 \mathrm{~g} / \mathrm{L}\end{array}$ & [173] \\
\hline $\begin{array}{l}\text { Fresh water } \\
\text { anammox sludge }\end{array}$ & $\begin{array}{l}350 \text { mL UASB } \\
\text { reactors }\end{array}$ & Continuous & $\mathrm{NaCl}: 3-30$ & $\begin{array}{l}\text { Dominant anammox bacteria } \\
\text { shifted from "Candidatus Brocadia } \\
\text { fulgida" to "C. Kuenenia } \\
\text { stuttgartiensis" }\end{array}$ & [159] \\
\hline Anammox sludge & $\begin{array}{l}2.2 \mathrm{~L} \mathrm{UASB} \\
\text { reactor }\end{array}$ & Continuous & $\mathrm{NaCl}: 35.1$ & Anammox performance collapsed & [160] \\
\hline
\end{tabular}

The effect of salinity on anammox performance was investigated in a wide range, up to $75 \mathrm{~g} / \mathrm{L}$, of $\mathrm{NaCl}$. A marine anammox bacterial consortium dominated by Planctomycete UKU-1 can resist a salt concentration of $75 \mathrm{~g} / \mathrm{L}$, but the nitrogen removal rate significantly declined [167]. Stable nitrogen removal was observed in this system with $\mathrm{NaCl}$ concentrations lower than $50 \mathrm{~g} / \mathrm{L}$. Most fresh water anammox bacteria were adversely affected at a salt shock load of $30 \mathrm{~g} / \mathrm{L} \mathrm{NaCl}$ and higher $[160,163-165,171]$. The response of anammox activity to salinity exposure typically depends on the adaptation process. Without adaptation, anammox activity in a 5 L UASB bioreactor decreased by $67.5 \%$ in the presence of $30 \mathrm{~g} / \mathrm{L} \mathrm{NaCl}[164]$, whereas the activity of adapted anammox biomass decreased by only $45.1 \%$ under the same salinity condition. Similarly, these values in a $50 \mathrm{~L}$ lab scale RBC were $96 \%$ and $58 \%$ for non-adapted and adapted anammox biomass, respectively [163]. No inhibition was detected when this reactor was fed with influent having salinity of $6 \mathrm{~g} / \mathrm{L}$. At a smaller scale batch test with $25 \mathrm{~mL}$ vials using anammox sludge dominated by "Candidatus Kuenenia stuttgartiensis", the $\mathrm{IC}_{50}$ value of $\mathrm{NaCl}$ was determined at $13.45 \mathrm{~g} / \mathrm{L}$ [26]. The inhibition of salinity shock on nitrogen removal performance of anammox was generally found in the range from 10-15 g/L [162,166,168-170,172,173]. A complete inhibition of anammox activity was observed in a $10 \mathrm{~L}$ MBBR reactor continuously fed with $\mathrm{NaCl}$ of $15 \mathrm{~g} / \mathrm{L}$ [168]. Nitrogen removal rate decreased significantly with $\mathrm{NaCl}$ levels higher than $10 \mathrm{~g} / \mathrm{L}$ loaded to a 2.5 L UASB reactor [166]. 
Except for the inhibitory effect on anammox activity at high salinity, the presence of salt in the anammox system exhibited various benefits to the operation of the anammox process. In a 2 L SBR reactor, the presence of $5-10 \mathrm{~g} / \mathrm{L} \mathrm{NaCl}$ improved the retention of biomass, which also improved nitrogen-removal performance [161]. Under this condition, anammox activity was slightly reduced at the initial stages but gradually increased thereafter. Similarly, the presence of $\mathrm{NaCl}$ was observed to enhance the aggregation of anammox biomass and stimulate anammox activity at $\mathrm{NaCl}$ concentrations of $6-15 \mathrm{~g} / \mathrm{L}$ [162]. In another study [170], the addition of $5 \mathrm{~g} / \mathrm{L} \mathrm{NaCl}$ and $\mathrm{CaCl}_{2}$ favored the formation of anammox biofilms in an $1 \mathrm{~L}$ SBR reactor operated in continuous mode. In addition, the maximal anammox activity was observed only at an $\mathrm{NaCl}$ concentration of $5 \mathrm{~g} / \mathrm{L}$ [171]. The stable activity of anammox under the transition from low to high salinity was explained through the change in dominant anammox bacteria. The 454 pyrosequencing of a freshwater anammox community indicated that dominant anammox bacteria shifted from "Candidatus Brocadia fulgida" to " $C$. Kuenenia stuttgartiensis" when the salinity of the influent changed from 3 to $30 \mathrm{~g} / \mathrm{L}$ during a 40 day adaptation [159]. There was also strong evidence that the increase in salinity triggered significant changes in the functional proteins of anammox bacteria in a $5 \mathrm{~L}$ non-woven biofilm reactor [173], which could be a main mechanism for salinity resistance in anammox.

\section{Optimizing Strategies for the Efficient Performance of the Anammox Process}

Several factors directly affect nitrogen-removal performance during the operation of an anammox system for wastewater treatment. Among them, temperature, $\mathrm{pH}, \mathrm{DO}$, nitrogen loading, and carbon source content primarily need to be precisely controlled to produce a steady effluent meeting the discharge requirements. The anammox process was observed to perform efficiently at high ambient temperatures and the practical low temperatures during winters represents the bottleneck in commercializing this technology in wastewater treatment. Therefore, an intensive investigation on the metabolism of key functional anammox bacteria at low temperatures through metagenomic analysis would enhance the feasibility of the wide application of anammox because a good performance of the anammox process at low temperatures has been recorded previously [41]. Monitoring $\mathrm{pH}$ of the influent to maintain it within the favorable range of anammox bacteria ( $\mathrm{pH}$ 6.7-8.3) is imperative because extremely low or high $\mathrm{pH}$ is detrimental to the nitrogen-removal efficiency of the anammox system. In the one-stage anammox process, the real-time control of DO through intermittent aeration is the most effective technique for balancing nitrite and ammonium levels for the anammox reaction and suppressing NOB activity [33]. Real wastewaters commonly contain high nitrogen concentration. Therefore, controlling influent nitrogen below the inhibition threshold by a reasonable loading rate and effluent recirculation would improve and stabilize the nitrogen removal rate in anammox systems. The presence of excess organic carbon sources in the influent of anammox systems can be overcome by controlling the activity of heterotrophic bacteria in a synergetic relationship with anammox bacteria. The heterotrophic bacteria might be heterotrophic denitrifiers that could partially remove the nitrate present in the systems or simple organic oxidizers that can maintain a suitable anaerobic niche around anammox granules. In another strategy, the excess organic carbon in the wastewater influent can be recycled and reused through further studies on the carbon footprint and capture technologies.

The sudden occurrence of some uncommon toxic organic and inorganic compounds owing to environmental disasters or accidents and the complexity of industrial wastewater can deteriorate or inhibit the normal activity of anammox systems. The recovery of anammox performance after deterioration can be achieved through adjustment of operating parameters together with the careful monitoring of performance, activity, and microbial dynamic changes in the anammox system. However, the thorough prior understanding of the relationship between operating parameters and the toxic effects of inhibitors on anammox bacteria, the adaptability of the current anammox sludge to the inhibitors, and the capability for recovery after deterioration of anammox systems is required. In this scheme, the pre-acclimation of the anammox sludge to these inhibitors before official operation might be an efficient precaution. When anammox sludge density was significantly reduced owing to the 
inhibitor, the addition of fresh anammox sludge through a stable influent loading might balance the anammox growth factor and relieve the activity loss through inhibition.

\section{Conclusions}

A stable and high nitrogen removal rate can only be achieved if operational parameters such as temperature, $\mathrm{pH}, \mathrm{DO}$, nitrogen concentration, and carbon concentration are controlled at appropriate levels. Under the same operational conditions, the nitrogen removal efficiency of various anammox systems could differ owing to the difference in dominant anammox species because the metabolism of each anammox community is different. Therefore, the operational conditions for each anammox type should be investigated individually to determine precise optimal conditions. Anammox inhibition by hyper-saturation of substrates such as nitrite, hypersalinity, or toxic compounds such as sulfides, toxic metals, phenols, alcohols, and antibiotics can be controlled and prevented using proper strategies. Some specific anammox species can perform efficiently under these severe environments in the presence of toxic compounds. Therefore, a careful understanding of both the characteristics of the wastewater influent and the existing anammox community of the bioreactor plays an important role in its operation. To date, major research on the anammox process has been limited to lab-scale research reactors and synthetic wastewaters. The investigation of real wastewaters such as landfill leachate, pharmaceutical wastewater, and swine wastewater with the effect of multiple environmental factors at pilot and industrial scales is required for the future study of anammox application. A complete online-monitoring system coupled with automatic control of operational factors developed through the assistance of artificial intelligent technology would be another interesting topic in future research on anammox.

Author Contributions: Data collection and summary, C.K. and V.K.N.; Manuscript preparation, S.C. and V.K.N. All authors have read and agreed to the published version of the manuscript.

Funding: This research was funded by the National Research Foundation of Korea (NRF), grant number 2018R1A2B6005645.

Acknowledgments: The authors express their gratitude to the Institute for Research \& Industry Cooperation, Pusan National University for their support on English editing of this manuscript.

Conflicts of Interest: The authors declare no conflict of interest.

\section{References}

1. Mulder, A. Anoxic ammonia oxidation. European Patent Office-EP 0327184 A1, 2 February 1989.

2. Laureni, M.; Falås, P.; Robin, O.; Wick, A.; Weissbrodt, D.G.; Nielsen, J.L.; Ternes, T.A.; Morgenroth, E.; Joss, A. Mainstream partial nitritation and anammox: Long-term process stability and effluent quality at low temperatures. Water Res. 2016, 101, 628-639. [CrossRef] [PubMed]

3. Tomaszewski, M.; Cema, G.; Ziembińska-Buczyńska, A. Influence of temperature and $\mathrm{pH}$ on the anammox process: A review and meta-analysis. Chemosphere 2017, 182, 203-214. [CrossRef] [PubMed]

4. Reino, C.; Suárez-Ojeda, M.E.; Pérez, J.; Carrera, J. Stable long-term operation of an upflow anammox sludge bed reactor at mainstream conditions. Water Res. 2018, 128, 331-340. [CrossRef] [PubMed]

5. Jiang, X.-Y.; Cheng, Y.-F.; Zhu, W.-Q.; Bai, Y.-H.; Xu, L.-Z.-J.; Wu, X.-Q.; Jin, R.-C. Effect of chromium on granule-based anammox processes. Bioresour. Technol. 2018, 260, 1-8. [CrossRef] [PubMed]

6. Arrigo, K.R. Marine microorganisms and global nutrient cycles. Nature 2005, 437, 349-355. [CrossRef]

7. Francis, C.A.; Beman, J.M.; Kuypers, M.M.M. New processes and players in the nitrogen cycle: The microbial ecology of anaerobic and archaeal ammonia oxidation. ISME J. 2007, 1, 19-27. [CrossRef]

8. Kartal, B.; Kuenen, J.G.; Van Loosdrecht, M.C.M. Sewage treatment with anammox. Science 2010, 328, 702-703. [CrossRef]

9. Cho, S.; Fujii, N.; Lee, T.; Okabe, S. Development of a simultaneous partial nitrification and anaerobic ammonia oxidation process in a single reactor. Bioresour. Technol. 2011, 102, 652-659. [CrossRef] 
10. De Cocker, P.; Bessiere, Y.; Hernandez-raquet, G.; Dubos, S.; Mozo, I.; Gaval, G. Bioresource Technology Enrichment and adaptation yield high anammox conversion rates under low temperatures. Bioresour. Technol. 2018, 250, 505-512. [CrossRef]

11. Kuenen, J.G.; Kartal, B.; Van Loosdrecht, M.C.M. Application of anammox for N-removal can turn sewage treatment plant into biofuel factory. Biofuels 2011, 2, 237-241. [CrossRef]

12. Cao, Y.; Van Loosdrecht, M.C.M.; Daigger, G.T. Mainstream partial nitritation-anammox in municipal wastewater treatment: Status, bottlenecks, and further studies. Appl. Microbiol. Biotechnol. 2017, 101, 1365-1383. [CrossRef] [PubMed]

13. Lackner, S.; Terada, A.; Smets, B.F. Heterotrophic activity compromises autotrophic nitrogen removal in membrane-aerated biofilms: Results of a modeling study. Water Res. 2008, 42, 1102-1112. [CrossRef] [PubMed]

14. Lackner, S.; Gilbert, E.M.; Vlaeminck, S.E.; Joss, A.; Horn, H.; van Loosdrecht, M.C.M. Full-scale partial nitritation/anammox experiences-An application survey. Water Res. 2014, 55, 292-303. [CrossRef] [PubMed]

15. Jetten, M.S.M.; Horn, S.J.; van Loosdrecht, M.C.M. Towards a more sustainable municipal wastewater treatment system. Water Sci. Technol. 1997, 35, 171-180. [CrossRef]

16. Wett, B. Solved upscaling problems for implementing deammonification of rejection water. Water Sci. Technol. 2006, 53, 121-128. [CrossRef]

17. Daigger, G.T. Oxygen and carbon requirements for biological nitrogen removal processes accomplishing nitrification, nitritation, and anammox. Water Environ. Res. 2014, 86, 204-209. [CrossRef]

18. Van Loosdrecht, M.C.M.; Brdjanovic, D. Anticipating the next century of wastewater treatment. Science 2014, 344, 1452-1453. [CrossRef]

19. Kartal, B.; De Almeida, N.M.; Maalcke, W.J.; Op den Camp, H.J.M.; Jetten, M.S.M.; Keltjens, J.T. How to make a living from anaerobic ammonium oxidation. FEMS Microbiol. Rev. 2013, 37, 428-461. [CrossRef]

20. Ma, H.; Zhang, Y.; Xue, Y.; Li, Y.Y. A new process for simultaneous nitrogen removal and phosphorus recovery using an anammox expanded bed reactor. Bioresour. Technol. 2018, 267, 201-208. [CrossRef]

21. Petrie, B.; Barden, R.; Kasprzyk-Hordern, B. A review on emerging contaminants in wastewaters and the environment: Current knowledge, understudied areas and recommendations for future monitoring. Water Res. 2014, 72, 3-27. [CrossRef]

22. Jin, R.-C.; Yang, G.-F.; Yu, J.-J.; Zheng, P. The inhibition of the Anammox process: A review. Chem. Eng. J. 2012, 197, 67-79. [CrossRef]

23. Alvarino, T.; Suarez, S.; Lema, J.M.; Omil, F. Understanding the removal mechanisms of PPCPs and the influence of main technological parameters in anaerobic UASB and aerobic CAS reactors. J. Hazard. Mater. 2014, 278, 506-513. [CrossRef] [PubMed]

24. De Graaff, M.S.; Temmink, H.; Zeeman, G.; van Loosdrecht, M.C.M.; Buisman, C.J.N. Autotrophic nitrogen removal from black water: Calcium addition as a requirement for settleability. Water Res. 2011, 45, 63-74. [CrossRef] [PubMed]

25. Strous, M.; Fuerst, J.A.; Kramer, E.H.M.; Logemann, S.; Muyzer, G.; Van De Pas-Schoonen, K.T.; Webb, R.; Kuenen, J.G.; Jetten, M.S.M. Missing lithotroph identified as new planctomycete. Nature 1999, 400, 446-449. [CrossRef] [PubMed]

26. Dapena-Mora, A.; Fernández, I.; Campos, J.L.; Mosquera-Corral, A.; Méndez, R.; Jetten, M.S.M. Evaluation of activity and inhibition effects on Anammox process by batch tests based on the nitrogen gas production. Enzyme Microb. Technol. 2007, 40, 859-865. [CrossRef]

27. Egli, K.; Fanger, U.; Alvarez, P.J.J.; Siegrist, H.; Van der Meer, J.R.; Zehnder, A.J.B. Enrichment and characterization of an anammox bacterium from a rotating biological contactor treating ammonium-rich leachate. Arch. Microbiol. 2001, 175, 198-207. [CrossRef]

28. Lotti, T.; Cordola, M.; Kleerebezem, R.; Caffaz, S.; Lubello, C.; van Loosdrecht, M.C.M. Inhibition effect of swine wastewater heavy metals and antibiotics on anammox activity. Water Sci. Technol. 2012, 66, 1519-1526. [CrossRef]

29. Lotti, T.; Kleerebezem, R.; Lubello, C.; van Loosdrecht, M.C.M. Physiological and kinetic characterization of a suspended cell anammox culture. Water Res. 2014, 60,1-14. [CrossRef]

30. Xu, G.; Zhou, Y.; Yang, Q.; Lee, Z.M.P.; Gu, J.; Lay, W.; Cao, Y.; Liu, Y. The challenges of mainstream deammonification process for municipal used water treatment. Appl. Microbiol. Biotechnol. 2015, 99, 2485-2490. [CrossRef] 
31. Lotti, T.; Kleerebezem, R.; van Loosdrecht, M.C.M. Effect of temperature change on anammox activity. Biotechnol. Bioeng. 2015, 112, 98-103. [CrossRef]

32. Park, G.; Takekawa, M.; Soda, S.; Ike, M.; Furukawa, K. Temperature dependence of nitrogen removal activity by anammox bacteria enriched at low temperatures. J. Biosci. Bioeng. 2017, 123, 505-511. [CrossRef] [PubMed]

33. Li, J.; Li, J.; Gao, R.; Wang, M.; Yang, L.; Wang, X.; Zhang, L.; Peng, Y. A critical review of one-stage anammox processes for treating industrial wastewater: Optimization strategies based on key functional microorganisms. Bioresour. Technol. 2018, 265, 498-505. [CrossRef] [PubMed]

34. Strous, M.; Van Gerven, E.; Zheng, P.; Kuenen, J.G.; Jetten, M.S.M. Ammonium removal from concentrated waste streams with the anaerobic ammonium oxidation (anammox) process in different reactor configurations. Water Res. 1997, 31, 1955-1962. [CrossRef]

35. Byrne, N.; Strous, M.; Crépeau, V.; Kartal, B.; Birrien, J.L.; Schmid, M.; Lesongeur, F.; Schouten, S.; Jaeschke, A.; Jetten, M.; et al. Presence and activity of anaerobic ammonium-oxidizing bacteria at deep-sea hydrothermal vents. ISME J. 2009, 3, 117-123. [CrossRef] [PubMed]

36. Jaescnke, A.; Abbas, B.; Zabel, M.; Hopmans, E.C.; Schouten, S.; Sinninghe Damsté, J.S. Molecular evidence for anaerobic ammonium-oxidizing (anammox) bacteria in continental shelf and slope sediments off northwest Africa. Limnol. Oceanogr. 2010, 55, 365-376. [CrossRef]

37. Zhu, G.; Xia, C.; Shanyun, W.; Zhou, L.; Liu, L.; Zhao, S. Occurrence, activity and contribution of anammox in some freshwater extreme environments. Environ. Microbiol. Rep. 2015, 7, 961-969. [CrossRef] [PubMed]

38. Castro-Barros, C.M.; Jia, M.; van Loosdrecht, M.C.M.; Volcke, E.I.P.; Winkler, M.K.H. Evaluating the potential for dissimilatory nitrate reduction by anammox bacteria for municipal wastewater treatment. Bioresour. Technol. 2017, 233, 363-372. [CrossRef]

39. Jetten, M.S.M.; Wagner, M.; Fuerst, J.; Van Loosdrecht, M.; Kuenen, G.; Strous, M. Microbiology and application of the anaerobic ammonium oxidation ('anammox') process. Curr. Opin. Biotechnol. 2001, 12, 283-288. [CrossRef]

40. Isanta, E.; Bezerra, T.; Fernández, I.; Suárez-Ojeda, M.E.; Pérez, J.; Carrera, J. Microbial community shifts on an anammox reactor after a temperature shock using 454-pyrosequencing analysis. Bioresour. Technol. 2015, 181, 207-213. [CrossRef]

41. He, S.; Chen, Y.; Qin, M.; Mao, Z.; Yuan, L.; Niu, Q.; Tan, X. Effects of temperature on anammox performance and community structure. Bioresour. Technol. 2018, 260, 186-195. [CrossRef]

42. Dosta, J.; Fern, I.; Alvarez, J.M. Short- and long-term effects of temperature on the Anammox process. J. Hazard. Mater. 2008, 154, 688-693. [CrossRef] [PubMed]

43. Gilbert, E.M.; Agrawal, S.; Schwartz, T.; Horn, H.; Lackner, S. Comparing different reactor configurations for Partial Nitritation/Anammox at low temperatures. Water Res. 2015, 81, 92-100. [CrossRef] [PubMed]

44. Fux, C.; Boehler, M.; Huber, P.; Brunner, I.; Siegrist, H. Biological treatment of ammonium-rich wastewater by partial nitritation and subsequent anaerobic ammonium oxidation (anammox) in a pilot plant. J. Biotechnol. 2002, 99, 295-306. [CrossRef]

45. Dapena-Mora, A.; Arrojo, B.; Campos, J.L.; Mosquera-Corral, A.; Méndez, R. Improvement of the settling properties of Anammox sludge in an SBR. J. Chem. Technol. Biotechnol. 2004, 79, 1417-1420. [CrossRef]

46. Han, P.; Huang, Y.T.; Lin, J.G.; Gu, J.D. A comparison of two 16S rRNA gene-based PCR primer sets in unraveling anammox bacteria from different environmental samples. Appl. Microbiol. Biotechnol. 2013, 97, 10521-10529. [CrossRef]

47. Isaka, K.; Suwa, Y.; Kimura, Y.; Yamagishi, T.; Sumino, T.; Tsuneda, S. Anaerobic ammonium oxidation (anammox) irreversibly inhibited by methanol. Appl. Microbiol. Biotechnol. 2008, 81, 379-385. [CrossRef]

48. Mulder, A.; van de Graaf, A.A.; Robertson, L.A.; Kuenen, J.G. Anaerobic ammonium oxidation discovered in a denitrifying fluidized bed reactor. FEMS Microbiol. Ecol. 1995, 16, 177-183. [CrossRef]

49. Vlaeminck, S.E.; De Clippeleir, H.; Verstraete, W. Microbial resource management of one-stage partial nitritation/anammox. Microb. Biotechnol. 2012, 5, 433-448. [CrossRef]

50. Ma, B.; Wang, S.; Cao, S.; Miao, Y.; Jia, F.; Du, R.; Peng, Y. Biological nitrogen removal from sewage via anammox: Recent advances. Bioresour. Technol. 2016, 200, 981-990. [CrossRef]

51. Jin, R.-C.; Yang, G.-F.; Zhang, Q.-Q.; Ma, C.; Yu, J.-J.; Xing, B.-S. The effect of sulfide inhibition on the ANAMMOX process. Water Res. 2013, 47, 1459-1469. [CrossRef] 
52. Jetten, M.S.M.; van Niftrik, L.; Strous, M.; Kartal, B.; Keltjens, J.T.; Op den Camp, H.J.M. Biochemistry and molecular biology of anammox bacteria. Crit. Rev. Biochem. Mol. Biol. 2009, 44, 65-84. [CrossRef]

53. Moss, F.R.; Shuken, S.R.; Mercer, J.A.M.; Cohen, C.M.; Weiss, T.M.; Boxer, S.G.; Burns, N.Z. Ladderane phospholipids form a densely packed membrane with normal hydrazine and anomalously low proton/hydroxide permeability. Proc. Natl. Acad. Sci. USA 2018, 115, 9098-9103. [CrossRef]

54. Rattray, J.E.; De Van Vossenberg, J.; Jaeschke, A.; Hopmans, E.C.; Wakeham, S.G.; Lavik, G.; Kuypers, M.M.M.; Strous, M.; Jetten, M.S.M.; Schouten, S.; et al. Impact of temperature on ladderane lipid distribution in anammox bacteria. Appl. Environ. Microbiol. 2010, 76, 1596-1603. [CrossRef]

55. Fernández, I.; Dosta, J.; Fajardo, C.; Campos, J.L.; Mosquera-Corral, A.; Méndez, R. Short- and long-term effects of ammonium and nitrite on the Anammox process. J. Environ. Manag. 2012, 95, S170-S174. [CrossRef]

56. Fernández, I.; Dosta, J.; Mata-Álvarez, J. A critical review of future trends and perspectives for the implementation of partial nitritation/anammox in the main line of municipal WWTPs. Desalin. Water Treat. 2016, 57, 27890-27898.

57. Hoekstra, M.; de Weerd, F.A.; Kleerebezem, R.; van Loosdrecht, M.C.M. Deterioration of the anammox process at decreasing temperatures and long SRTs. Environ. Technol. 2018, 39, 658-668. [CrossRef]

58. Laureni, M.; Weissbrodt, D.G.; Szivák, I.; Robin, O.; Nielsen, J.L.; Morgenroth, E.; Joss, A. Activity and growth of anammox biomass on aerobically pre-treated municipal wastewater. Water Res. 2015, 80, 325-336. [CrossRef]

59. Val del Rio, A.; Pichel, A.; Fernandez-Gonzalez, N.; Pedrouso, A.; Fra-Vázquez, A.; Morales, N.; Mendez, R.; Campos, J.L.; Mosquera-Corral, A. Performance and microbial features of the partial nitritation-anammox process treating fish canning wastewater with variable salt concentrations. J. Environ. Manag. 2018, 208, 112-121. [CrossRef]

60. Ma, B.; Peng, Y.; Zhang, S.; Wang, J.; Gan, Y.; Chang, J.; Wang, S.; Wang, S.; Zhu, G. Performance of anammox UASB reactor treating low strength wastewater under moderate and low temperatures. Bioresour. Technol. 2013, 129, 606-611. [CrossRef]

61. Wang, D.; Wang, Q.; Laloo, A.; Xu, Y.; Bond, P.L.; Yuan, Z. Achieving stable nitritation for mainstream deammonification by combining free nitrous acid-based sludge treatment and oxygen limitation. Sci. Rep. 2016, 6, 520-527. [CrossRef]

62. Park, H.D.; Noguera, D.R. Characterization of two ammonia-oxidizing bacteria isolated from reactors operated with low dissolved oxygen concentrations. J. Appl. Microbiol. 2007, 102, 1401-1417. [CrossRef]

63. Van Der Star, W.R.L.; Miclea, A.I.; Van Dongen, U.G.J.M.; Muyzer, G.; Picioreanu, C.; Van Loosdrecht, M.C.M. The membrane bioreactor: A novel tool to grow anammox bacteria as free cells. Biotechnol. Bioeng. 2008, 101, 286-294. [CrossRef]

64. Van Niftrik, L.; Jetten, M.S.M. Anaerobic Ammonium-oxidizing bacteria: Unique microorganisms with exceptional properties. Microbiol. Mol. Biol. Rev. 2012, 76, 585-596. [CrossRef] [PubMed]

65. Isaka, K.; Date, Y.; Sumino, T.; Yoshie, S.; Tsuneda, S. Growth characteristic of anaerobic ammonium-oxidizing bacteria in an anaerobic biological filtrated reactor. Appl. Microbiol. Biotechnol. 2006, 70, 47-52. [CrossRef] [PubMed]

66. Awata, T.; Kindaichi, T.; Ozaki, N.; Ohashi, A. Biomass yield efficiency of the marine anammox bacterium, "candidatus scalindua sp.," is affected by salinity. Microbes Environ. 2015, 30, 86-91. [CrossRef] [PubMed]

67. Yang, J.; Zhang, L.; Hira, D.; Fukuzaki, Y.; Furukawa, K. Anammox treatment of high-salinity wastewater at ambient temperature. Bioresour. Technol. 2011, 102, 2367-2372. [CrossRef] [PubMed]

68. Ganigué, R.; Gabarró, J.; Sànchez-Melsió, A.; Ruscalleda, M.; López, H.; Vila, X.; Colprim, J.; Balaguer, M.D. Long-term operation of a partial nitritation pilot plant treating leachate with extremely high ammonium concentration prior to an anammox process. Bioresour. Technol. 2009, 100, 5624-5632. [CrossRef]

69. Roller, B.R.K.; Stoddard, S.F.; Schmidt, T.M. Exploiting rRNA Operon copy number to investigate bacterial reproductive strategies HHS public access author manuscript. Nat. Microbiol. 2017, 1, 1-19.

70. Tang, C.; Zheng, P.; Mahmood, Q.; Chen, J. Start-up and inhibition analysis of the Anammox process seeded with anaerobic granular sludge. J. Ind. Microbiol. Biotechnol. 2009, 36, 1093-1100. [CrossRef]

71. Jung, J.Y.; Kang, S.H.; Chung, Y.C.; Ahn, D.H. Factors affecting the activity of anammox bacteria during start up in the continuous culture reactor. Water Sci. Technol. 2007, 55, 459-468. [CrossRef] 
72. Ni, S.Q.; Fessehaie, A.; Lee, P.H.; Gao, B.Y.; Xu, X.; Sung, S. Interaction of anammox bacteria and inactive methanogenic granules under high nitrogen selective pressure. Bioresour. Technol. 2010, 101, 6910-6915. [CrossRef] [PubMed]

73. Third, K.A.; Paxman, J.; Schmid, M.; Strous, M.; Jetten, M.S.M.; Cord-Ruwisch, R. Enrichment of anammox from activated sludge and its application in the CANON process. Microb. Ecol. 2005, 49, 236-244. [CrossRef] [PubMed]

74. Chen, J.; Ji, Q.; Zheng, P.; Chen, T.; Wang, C.; Mahmood, Q. Floatation and control of granular sludge in a high-rate anammox reactor. Water Res. 2010, 44, 3321-3328. [CrossRef] [PubMed]

75. Wang, T.; Zhang, H.; Gao, D.; Yang, F.; Zhang, G. Comparison between MBR and SBR on Anammox start-up process from the conventional activated sludge. Bioresour. Technol. 2012, 122, 78-82. [CrossRef]

76. He, S.; Niu, Q.; Ma, H.; Zhang, Y.; Li, Y.Y. The treatment performance and the bacteria preservation of anammox: A review. Water Air. Soil Pollut. 2015, 226, 163. [CrossRef]

77. Gonzalez-Martinez, A.; Muñoz-Palazon, B.; Rodriguez-Sanchez, A.; Gonzalez-Lopez, J. New concepts in anammox processes for wastewater nitrogen removal: Recent advances and future prospects. FEMS Microbiol. Lett. 2018, 365, 1-10. [CrossRef]

78. Thamdrup, B.; Dalsgaard, T.; Jensen, M.M.; Ulloa, O.; Farías, L.; Escribano, R. Anaerobic ammonium oxidation in the oxygen-deficient waters off northern Chile. Limnol. Oceanogr. 2006, 51, 2145-2156. [CrossRef]

79. Ward, B.B.; Devol, A.H.; Rich, J.J.; Chang, B.X.; Bulow, S.E.; Naik, H.; Pratihary, A.; Jayakumar, A. Denitrification as the dominant nitrogen loss process in the Arabian Sea. Nature 2009, 461, 78-81. [CrossRef]

80. Koeve, W.; Kähler, P. Heterotrophic denitrification vs. autotrophic anammox-quantifying collateral effects on the oceanic carbon cycle. Biogeosciences 2010, 7, 2327-2337. [CrossRef]

81. Dalsgaard, T.; Thamdrup, B.; Farías, L.; Revsbech, N.P. Anammox and denitrification in the oxygen minimum zone of the eastern South Pacific. Limnol. Oceanogr. 2012, 57, 1331-1346. [CrossRef]

82. Dähnke, K.; Thamdrup, B. Isotope fractionation and isotope decoupling during anammox and denitrification in marine sediments. Limnol. Oceanogr. 2016, 61, 610-624. [CrossRef]

83. Morales, N.; Val Del Río, A.; Vázquez-Padín, J.R.; Gutiérrez, R.; Fernández-González, R.; Icaran, P.; Rogalla, F.; Campos, J.L.; Méndez, R.; Mosquera-Corral, A. Influence of dissolved oxygen concentration on the start-up of the anammox-based process: ELAN ${ }^{\circledR}$. Water Sci. Technol. 2015, 72, 520-527. [CrossRef] [PubMed]

84. Liu, S.; Yang, F.; Xue, Y.; Gong, Z.; Chen, H.; Wang, T.; Su, Z. Evaluation of oxygen adaptation and identification of functional bacteria composition for anammox consortium in non-woven biological rotating contactor. Bioresour. Technol. 2008, 99, 8273-8279. [CrossRef] [PubMed]

85. Blackburne, R.; Yuan, Z.; Keller, J. Partial nitrification to nitrite using low dissolved oxygen concentration as the main selection factor. Biodegradation 2008, 19, 303-312. [CrossRef]

86. Wang, T.; Zhang, H.; Yang, F. Performance of Anammox process and low-oxygen adaptability of Anammox biofilms in a FBR with small ring non-woven carriers. Ecol. Eng. 2016, 86, 126-134. [CrossRef]

87. Nielsen, M.; Bollmann, A.; Sliekers, O.; Jetten, M.; Schmid, M.; Strous, M.; Schmidt, I.; Larsen, L.H.; Nielsen, L.P.; Revsbech, N.P. Kinetics, diffusional limitation and microscale distribution of chemistry and organisms in a CANON reactor. FEMS Microbiol. Ecol. 2005, 51, 247-256. [CrossRef]

88. Bellucci, M.; Ofiţeru, I.D.; Graham, D.W.; Head, I.M.; Curtis, T.P. Low-dissolved-oxygen nitrifying systems exploit ammonia-oxidizing bacteria with unusually high yields. Appl. Environ. Microbiol. 2011, 77, 7787-7796. [CrossRef]

89. Xie, G.J.; Liu, T.; Cai, C.; Hu, S.; Yuan, Z. Achieving high-level nitrogen removal in mainstream by coupling anammox with denitrifying anaerobic methane oxidation in a membrane biofilm reactor. Water Res. 2018, 131, 196-204. [CrossRef]

90. Zhang, B.; Zhao, J.; Zuo, J.; Shi, X.; Gong, J.; Ren, H. Realizing stable operation of anaerobic ammonia oxidation at low temperatures treating low strength synthetic wastewater. J. Environ. Sci. 2019, 75, 193-200. [CrossRef]

91. Martins, T.H.; Souza, T.S.O; Varesche, M.B.A. The Influence of stirring speed, temperature and initial nitrogen concentration on specific anammox activity. Braz. Arch. Biol. Technol. 2018, 60, 1-11. [CrossRef]

92. Puyol, D.; Carvajal-Arroyo, J.M.; Sierra-Alvarez, R.; Field, J.A. Nitrite (not free nitrous acid) is the main inhibitor of the anammox process at common $\mathrm{pH}$ conditions. Biotechnol. Lett. 2014, 36, 547-551. [CrossRef] [PubMed] 
93. Lackner, S.; Horn, H. Evaluating operation strategies and process stability of a single stage nitritation-anammox SBR by use of the oxidation-reduction potential (ORP). Bioresour. Technol. 2012, 107, 70-77. [CrossRef] [PubMed]

94. Cho, S.; Takahashi, Y.; Fujii, N.; Yamada, Y.; Satoh, H.; Okabe, S. Nitrogen removal performance and microbial community analysis of an anaerobic up-flow granular bed anammox reactor. Chemosphere 2010, 78, 1129-1135. [CrossRef] [PubMed]

95. Tian, Z.; Zeng, P.; Song, Y.; Li, D.; Zhang, J. Nitrogen removal potential and biofilm characteristics in the anaerobic ammonium oxidation ('ANAMMOX') biofilter reactor. In Proceedings of the 4th International Conference on Bioinformatics and Biomedical Engineering, iCBBE, Chengdu, China, 18-20 June 2010.

96. Van Dongen, U.; Jetten, M.S.M.; Loosdrecht, M.C.M. Van Ammonium Rich Wastewater. Growth Lakel. 2001, 44, 153-160.

97. Winkler, M.K.H.; Kleerebezem, R.; Van Loosdrecht, M.C.M. Integration of anammox into the aerobic granular sludge process for main stream wastewater treatment at ambient temperatures. Water Res. 2012, 46, 136-144. [CrossRef] [PubMed]

98. Winkler, M.K.H.; Yang, J.; Kleerebezem, R.; Plaza, E.; Trela, J.; Hultman, B.; van Loosdrecht, M.C.M. Nitrate reduction by organotrophic Anammox bacteria in a nitritation/anammox granular sludge and a moving bed biofilm reactor. Bioresour. Technol. 2012, 114, 217-223. [CrossRef] [PubMed]

99. Molinuevo, B.; García, M.C.; Karakashev, D.; Angelidaki, I. Anammox for ammonia removal from pig manure effluents: Effect of organic matter content on process performance. Bioresour. Technol. 2009, 100, 2171-2175. [CrossRef]

100. Takekawa, M.; Park, G.; Soda, S.; Ike, M. Simultaneous anammox and denitrification (SAD) process in sequencing batch reactors. Bioresour. Technol. 2014, 174, 159-166. [CrossRef]

101. Bi, Z.; Qiao, S.; Zhou, J.; Tang, X.; Zhang, J. Fast start-up of Anammox process with appropriate ferrous iron concentration. Bioresour. Technol. 2014, 170, 506-512. [CrossRef]

102. García-Ruiz, M.J.; Maza-Márquez, P.; González-López, J.; Osorio, F. Nitrogen removal capacity and bacterial community dynamics of a Canon biofilter system at different organic matter concentrations. Chemosphere 2018, 193, 591-601. [CrossRef]

103. Kartal, B.; Kuypers, M.M.M.; Lavik, G.; Schalk, J.; Op Den Camp, H.J.M.; Jetten, M.S.M.; Strous, M. Anammox bacteria disguised as denitrifiers: Nitrate reduction to dinitrogen gas via nitrite and ammonium. Environ. Microbiol. 2007, 9, 635-642. [CrossRef] [PubMed]

104. Ruscalleda, M.; López, H.; Ganigué, R.; Puig, S.; Balaguer, M.D.; Colprim, J. Heterotrophic denitrification on granular anammox SBR treating urban landfill leachate. Water Sci. Technol. 2008, 58, 1749-1755. [CrossRef] [PubMed]

105. Kartal, B.; Rattray, J.; van Niftrik, L.A.; van de Vossenberg, J.; Schmid, M.C.; Webb, R.I.; Schouten, S.; Fuerst, J.A.; Damsté, J.S.; Jetten, M.S.M.; et al. Candidatus "Anammoxoglobus propionicus" a new propionate oxidizing species of anaerobic ammonium oxidizing bacteria. Syst. Appl. Microbiol. 2007, 30, 39-49. [CrossRef] [PubMed]

106. Chen, C.; Sun, F.; Zhang, H.; Wang, J.; Shen, Y.; Liang, X. Evaluation of COD effect on anammox process and microbial communities in the anaerobic baffled reactor (ABR). Bioresour. Technol. 2016, 216, 571-578. [CrossRef]

107. Kimura, Y.; Isaka, K.; Kazama, F. Effects of inorganic carbon limitation on anaerobic ammonium oxidation (anammox) activity. Bioresour. Technol. 2011, 102, 4390-4394. [CrossRef]

108. Ma, Y.; Sundar, S.; Park, H.; Chandran, K. The effect of inorganic carbon on microbial interactions in a biofilm nitritation-anammox process. Water Res. 2015, 70, 246-254. [CrossRef]

109. Carvajal-Arroyo, J.M.; Puyol, D.; Li, G.; Lucero-Acuña, A.; Sierra-Álvarez, R.; Field, J.A. Pre-exposure to nitrite in the absence of ammonium strongly inhibits anammox. Water Res. 2014, 48, 52-60. [CrossRef]

110. Li, G.; Vilcherrez, D.; Carvajal-Arroyo, J.M.; Sierra-Alvarez, R.; Field, J.A. Exogenous nitrate attenuates nitrite toxicity to anaerobic ammonium oxidizing (anammox) bacteria. Chemosphere 2016, 144, 2360-2367. [CrossRef]

111. Lotti, T.; van der Star, W.R.L.; Kleerebezem, R.; Lubello, C.; van Loosdrecht, M.C.M. The effect of nitrite inhibition on the anammox process. Water Res. 2012, 46, 2559-2569. [CrossRef] 
112. Raudkivi, M.; Zekker, I.; Rikmann, E.; Vabamäe, P.; Kroon, K.; Tenno, T. Nitrite inhibition and limitation-The effect of nitrite spiking on anammox biofilm, suspended and granular biomass. Water Sci. Technol. 2017, 75, 313-321. [CrossRef]

113. Carvajal-Arroyo, J.M.; Sun, W.; Sierra-Alvarez, R.; Field, J.A. Inhibition of anaerobic ammonium oxidizing (anammox) enrichment cultures by substrates, metabolites and common wastewater constituents. Chemosphere 2013, 91, 22-27. [CrossRef] [PubMed]

114. Bettazzi, E.; Caffaz, S.; Vannini, C.; Lubello, C. Nitrite inhibition and intermediates effects on Anammox bacteria: A batch-scale experimental study. Process Biochem. 2010, 45, 573-580. [CrossRef]

115. Kimura, Y.; Isaka, K.; Kazama, F.; Sumino, T. Effects of nitrite inhibition on anaerobic ammonium oxidation. Appl. Microbiol. Biotechnol. 2010, 86, 359-365. [CrossRef] [PubMed]

116. Zekker, I.; Rikmann, E.; Kroon, K.; Mandel, A.; Mihkelson, J.; Tenno, T.; Tenno, T. Ameliorating nitrite inhibition in a low-temperature nitritation-anammox MBBR using bacterial intermediate nitric oxide. Int. J. Environ. Sci. Technol. 2017, 14, 2343-2356. [CrossRef]

117. Zekker, I.; Rikmann, E.; Tenno, T.; Loorits, L.; Kroon, K.; Fritze, H.; Tuomivirta, T.; Vabamäe, P.; Raudkivi, M.; Mandel, A.; et al. Nitric oxide for anammox recovery in a nitrite-inhibited deammonification system. Environ. Technol. 2015, 36, 2477-2487. [CrossRef]

118. Yang, G.-F.; Jin, R.-C. The joint inhibitory effects of phenol, copper (II), oxytetracycline (OTC) and sulfide on Anammox activity. Bioresour. Technol. 2012, 126, 187-192. [CrossRef]

119. Val del Río, Á.; da Silva, T.; Martins, T.H.; Foresti, E.; Campos, J.L.; Méndez, R.; Mosquera-Corral, A. Partial nitritation-anammox granules: Short-term inhibitory effects of seven metals on anammox activity. Water Air Soil Pollut. 2017, 228, 439. [CrossRef]

120. Zhang, Z.-Z.; Zhang, Q.-Q.; Xu, J.-J.; Deng, R.; Ji, Z.-Q.; Wu, Y.-H.; Jin, R.-C. Evaluation of the inhibitory effects of heavy metals on anammox activity: A batch test study. Bioresour. Technol. 2016, 200, 208-216. [CrossRef]

121. Guo, Q.; Yang, C.-C.; Xu, J.-L.; Hu, H.-Y.; Huang, M.; Shi, M.-L.; Jin, R.-C. Individual and combined effects of substrate, heavy metal and hydraulic shocks on an anammox system. Sep. Purif. Technol. 2015, 154, 128-136. [CrossRef]

122. Yang, G.-F.; Ni, W.-M.; Wu, K.; Wang, H.; Yang, B.-E.; Jia, X.-Y.; Jin, R.-C. The effect of Cu(II) stress on the activity, performance and recovery on the Anaerobic Ammonium-Oxidizing (Anammox) process. Chem. Eng. J. 2013, 226, 39-45. [CrossRef]

123. Kimura, Y.; Isaka, K. Evaluation of inhibitory effects of heavy metals on anaerobic ammonium oxidation (anammox) by continuous feeding tests. Appl. Microbiol. Biotechnol. 2014, 98, 6965-6972. [CrossRef]

124. Li, G.; Puyol, D.; Carvajal-Arroyo, J.M.; Sierra-Alvarez, R.; Field, J.A. Inhibition of anaerobic ammonium oxidation by heavy metals. J. Chem. Technol. Biotechnol. 2015, 90, 830-837. [CrossRef]

125. Daverey, A.; Chen, Y.-C.; Sung, S.; Lin, J.-G. Effect of zinc on anammox activity and performance of simultaneous partial nitrification, anammox and denitrification (SNAD) process. Bioresour. Technol. 2014, 165, 105-110. [CrossRef] [PubMed]

126. Zhang, Q.-Q.; Zhang, Z.-Z.; Guo, Q.; Wang, J.-J.; Wang, H.-Z.; Jin, R.-C. Analyzing the revolution of anaerobic ammonium oxidation (anammox) performance and sludge characteristics under zinc inhibition. Appl. Microbiol. Biotechnol. 2015, 99, 3221-3232. [CrossRef] [PubMed]

127. Zhang, X.; Chen, Z.; Ma, Y.; Zhou, Y.; Zhao, S.; Wang, L.; Zhai, H. Influence of elevated Zn (II) on Anammox system: Microbial variation and zinc tolerance. Bioresour. Technol. 2018, 251, 108-113. [CrossRef] [PubMed]

128. Bi, Z.; Qiao, S.; Zhou, J.; Tang, X.; Cheng, Y. Inhibition and recovery of Anammox biomass subjected to short-term exposure of $\mathrm{Cd}, \mathrm{Ag}, \mathrm{Hg}$ and Pb. Chem. Eng. J. 2014, 244, 89-96. [CrossRef]

129. Yu, C.; Song, Y.-X.; Chai, L.-Y.; Duan, C.-S.; Tang, C.-J.; Ali, M.; Peng, C. Comparative evaluation of short-term stress of $\mathrm{Cd}(\mathrm{II}), \mathrm{Hg}(\mathrm{II}), \mathrm{Pb}(\mathrm{II}), \mathrm{As}(\mathrm{III})$ and $\mathrm{Cr}(\mathrm{VI})$ on anammox granules by batch test. J. Biosci. Bioeng. 2016, 122, 722-729. [CrossRef]

130. Nie, J.; Pan, Y.; Shi, J.; Guo, Y.; Yan, Z.; Duan, X.; Xu, M. A comparative study on the uptake and toxicity of nickel added in the form of different salts to maize seedlings. Int. J. Environ. Res. Public Health 2015, 12, 15075-15087. [CrossRef]

131. Van de Graaf, A.A.; de Bruijn, P.; Robertson, L.A.; Jetten, M.S.M.; Kuenen, J.G. Autotrophic growth of anaerobic ammonium-oxidizing micro-organisms in a fluidized bed reactor. Microbiology 1996, 142, 2187-2196. [CrossRef] 
132. Jensen, M.M.; Thamdrup, B.; Dalsgaard, T. Effects of specific inhibitors on anammox and denitrification in marine sediments. Appl. Environ. Microbiol. 2007, 73, 3151-3158. [CrossRef]

133. Güven, D.; Dapena, A.; Kartal, B.; Schmid, M.C.; Maas, B.; van de Pas-Schoonen, K.; Sozen, S.; Mendez, R.; Op den Camp, H.J.M.; Jetten, M.S.M.; et al. Propionate oxidation by and methanol inhibition of anaerobic ammonium-oxidizing bacteria. Appl. Environ. Microbiol. 2005, 71, 1066-1071. [CrossRef] [PubMed]

134. Oshiki, M.; Shimokawa, M.; Fujii, N.; Satoh, H.; Okabe, S. Physiological characteristics of the anaerobic ammonium-oxidizing bacterium “Candidatus Brocadia sinica.". Microbiology 2011, 157, 1706-1713. [CrossRef] [PubMed]

135. Schalk, J.; de Vries, J.S.; Kuenen, J.S.; Jetten, M.S.M. Involvement of a novel hydroxylamine oxidoreductase in anaerobic ammonium oxidation. Biochemistry 2000, 39, 5405-5412. [CrossRef] [PubMed]

136. Tang, C.-J.; Zheng, P.; Zhang, L.; Chen, J.-W.; Mahmood, Q.; Chen, X.-G.; Hu, B.-L.; Wang, C.-H.; Yu, Y. Enrichment features of anammox consortia from methanogenic granules loaded with high organic and methanol contents. Chemosphere 2010, 79, 613-619. [CrossRef]

137. Yeom, S.H.; Daugulis, A.J.; Lee, S.H. Bioremediation of phenol-contaminated water and soil using magnetic polymer beads. Process Biochem. 2010, 45, 1582-1586. [CrossRef]

138. Zhao, L.; Wu, Q.; Ma, A. Biodegradation of phenolic contaminants: Current Status and perspectives. IOP Conf. Ser. Earth Environ. Sci. 2018, 111, 012024. [CrossRef]

139. Dosta, J.; Nieto, J.M.; Vila, J.; Grifoll, M.; Mata-Álvarez, J. Phenol removal from hypersaline wastewaters in a Membrane Biological Reactor (MBR): Operation and microbiological characterisation. Bioresour. Technol. 2011, 102, 4013-4020. [CrossRef]

140. Toh, S.; Ashbolt, N. Adaptation of anaerobic ammonium-oxidising consortium to synthetic coke-ovens wastewater. Appl. Microbiol. Biotechnol. 2002, 59, 344-352.

141. Oshiki, M.; Masuda, Y.; Yamaguchi, T.; Araki, N. Synergistic inhibition of anaerobic ammonium oxidation (anammox) activity by phenol and thiocyanate. Chemosphere 2018, 213, 498-506. [CrossRef]

142. Jin, R.C.; Zhang, Q.Q.; Yang, G.F.; Xing, B.S.; Ji, Y.X.; Chen, H. Evaluating the recovery performance of the ANAMMOX process following inhibition by phenol and sulfide. Bioresour. Technol. 2013, 142, 162-170. [CrossRef]

143. Yang, G.F.; Guo, X.L.; Chen, S.X.; Liu, J.H.; Guo, L.X.; Jin, R.C. The evolution of Anammox performance and granular sludge characteristics under the stress of phenol. Bioresour. Technol. 2013, 137, 332-339. [CrossRef] [PubMed]

144. Pereira, A.D.; Leal, C.D.; Dias, M.F.; Etchebehere, C.; Chernicharo, C.A.L.; De Araújo, J.C. Effect of phenol on the nitrogen removal performance and microbial community structure and composition of an anammox reactor. Bioresour. Technol. 2014, 166, 103-111. [CrossRef] [PubMed]

145. Guo, Q.; Shi, Z.-J.; Yang, C.-C.; Huang, M.; Xu, J.-L.; Xu, Y.-Q.; Ni, W.-M.; Jin, R.-C. Individual and combined inhibition of phenol and thiocyanate on microbial activity of partial nitritation. Environ. Sci. Pollut. Res. 2017, 24, 14207-14217. [CrossRef] [PubMed]

146. Lyu, L.; Zhang, K.; Li, Z.; Ma, Y.; Chai, T.; Pan, Y.; Wang, X.; Li, S.; Zhu, T. Inhibition of anammox activity by phenol: Suppression effect, community analysis and mechanism simulation. Int. Biodeterior. Biodegradation 2019, 141, 30-38. [CrossRef]

147. Toh, S.K.; Webb, R.I.; Ashbolt, N.J. Enrichment of Autotrophic Anaerobic Ammonium-Oxidizing Consortia from Various Wastewaters. Microb. Ecol. 2002, 43, 154-167. [CrossRef] [PubMed]

148. Van de Graaf, A.A.; Mulder, A.; de Bruijn, P.; Jetten, M.S.; Robertson, L.A.; Kuenen, J.G. Anaerobic oxidation of ammonium is a biologically mediated process. Appl. Environ. Microbiol. 1995, 61, 1246-1251. [PubMed]

149. Ramos, C.; Fernández, I.; Suárez-Ojeda, M.E.; Carrera, J. Inhibition of the anammox activity by aromatic compounds. Chem. Eng. J. 2015, 279, 681-688. [CrossRef]

150. Guan, Y.; Wang, B.; Gao, Y.; Liu, W.; Zhao, X.; Huang, X.; Yu, J. Occurrence and fate of antibiotics in the aqueous environment and their removal by constructed wetlands in China: A review. Pedosphere 2017, 27, 42-51. [CrossRef]

151. Kümmerer, K. Antibiotics in the aquatic environment-A review-Part I. Chemosphere 2009, 75, 417-434. [CrossRef] 
152. Fernández, I.; Mosquera-Corral, A.; Campos, J.L.; Méndez, R. Operation of an Anammox SBR in the presence of two broad-spectrum antibiotics. Process Biochem. 2009, 44, 494-498. [CrossRef]

153. Zhang, Z.-Z.; Zhang, Q.-Q.; Guo, Q.; Chen, Q.-Q.; Jiang, X.-Y.; Jin, R.-C. Anaerobic ammonium-oxidizing bacteria gain antibiotic resistance during long-term acclimatization. Bioresour. Technol. 2015, 192, 756-764. [CrossRef] [PubMed]

154. Shi, Z.-J.; Hu, H.-Y.; Shen, Y.-Y.; Xu, J.-J.; Shi, M.-L.; Jin, R.-C. Long-term effects of oxytetracycline (OTC) on the granule-based anammox: Process performance and occurrence of antibiotic resistance genes. Biochem. Eng. J. 2017, 127, 110-118. [CrossRef]

155. Noophan, P.; Narinhongtong, P.; Wantawin, C.; Munakata-Marr, J. Effects of oxytetracycline on anammox activity. J. Environ. Sci. Heal. Part A Toxic/Hazard. Subst. Environ. Eng. 2012, 47, 873-877. [CrossRef] [PubMed]

156. Yang, G.-F.; Zhang, Q.-Q.; Jin, R.-C. Changes in the nitrogen removal performance and the properties of granular sludge in an Anammox system under oxytetracycline (OTC) stress. Bioresour. Technol. 2013, 129, 65-71. [CrossRef]

157. Jin, R.-C.; Zheng, P.; Mahmood, Q.; Hu, B.-L. Osmotic stress on nitrification in an airlift bioreactor. J. Hazard. Mater. 2007, 146, 148-154. [CrossRef]

158. Xiao, Y.; Roberts, D.J. A review of anaerobic treatment of saline wastewater. Environ. Technol. 2010, 31, 1025-1043. [CrossRef]

159. Gonzalez-Silva, B.M.; Rønning, A.J.; Andreassen, I.K.; Bakke, I.; Cervantes, F.J.; Østgaard, K.; Vadstein, O. Changes in the microbial community of an anammox consortium during adaptation to marine conditions revealed by 454 pyrosequencing. Appl. Microbiol. Biotechnol. 2017, 101, 5149-5162. [CrossRef]

160. Lu, H.; Li, Y.; Shan, X.; Abbas, G.; Zeng, Z.; Kang, D.; Wang, Y.; Zheng, P.; Zhang, M. A holistic analysis of ANAMMOX process in response to salinity: From adaptation to collapse. Sep. Purif. Technol. 2019, 215, 342-350. [CrossRef]

161. Fernández, I.; Vázquez-Padín, J.R.; Mosquera-Corral, A.; Campos, J.L.; Méndez, R. Biofilm and granular systems to improve Anammox biomass retention. Biochem. Eng. J. 2008, 42, 308-313. [CrossRef]

162. Dapena-Mora, A.; Vázquez-Padín, J.R.; Campos, J.L.; Mosquera-Corral, A.; Jetten, M.S.M.; Méndez, R. Monitoring the stability of an Anammox reactor under high salinity conditions. Biochem. Eng. J. 2010, 51, 167-171. [CrossRef]

163. Windey, K.; De Bo, I.; Verstraete, W. Oxygen-limited autotrophic nitrification-denitrification (OLAND) in a rotating biological contactor treating high-salinity wastewater. Water Res. 2005, 39, 4512-4520. [CrossRef] [PubMed]

164. Kartal, B.; Koleva, M.; Arsov, R.; van der Star, W.; Jetten, M.S.M.; Strous, M. Adaptation of a freshwater anammox population to high salinity wastewater. J. Biotechnol. 2006, 126, 546-553. [CrossRef] [PubMed]

165. Liu, C.; Yamamoto, T.; Nishiyama, T.; Fujii, T.; Furukawa, K. Effect of salt concentration in anammox treatment using non woven biomass carrier. J. Biosci. Bioeng. 2009, 107, 519-523. [CrossRef] [PubMed]

166. Ma, C.; Jin, R.-C.; Yang, G.-F.; Yu, J.-J.; Xing, B.-S.; Zhang, Q.-Q. Impacts of transient salinity shock loads on Anammox process performance. Bioresour. Technol. 2012, 112, 124-130. [CrossRef] [PubMed]

167. Wei, Q.; Kawagoshi, Y.; Huang, X.; Hong, N.; Van Duc, L.; Yamashita, Y.; Hama, T. Nitrogen removal properties in a continuous marine anammox bacteria reactor under rapid and extensive salinity changes. Chemosphere 2016, 148, 444-451. [CrossRef] [PubMed]

168. Malovanyy, A.; Plaza, E.; Trela, J.; Malovanyy, M. Ammonium removal by partial nitritation and Anammox processes from wastewater with increased salinity. Environ. Technol. 2015, 36, 595-604. [CrossRef]

169. Chen, H.; Ma, C.; Ji, Y.-X.; Ni, W.-M.; Jin, R.-C. Evaluation of the efficacy and regulation measures of the anammox process under salty conditions. Sep. Purif. Technol. 2014, 132, 584-592. [CrossRef]

170. Fernández, I.; Bravo, J.I.; Mosquera-Corral, A.; Pereira, A.; Campos, J.L.; Méndez, R.; Melo, L.F. Influence of the shear stress and salinity on Anammox biofilms formation: Modelling results. Bioprocess Biosyst. Eng. 2014, 37, 1955-1961. [CrossRef]

171. Jiang, X.; Hou, L.; Zheng, Y.; Liu, M.; Yin, G.; Gao, J.; Li, X.; Wang, R.; Yu, C.; Lin, X. Salinity-driven shifts in the activity, diversity, and abundance of anammox bacteria of estuarine and coastal wetlands. Phys. Chem. Earth Parts A/B/C 2017, 97, 46-53. [CrossRef] 
172. Xing, H.; Wang, H.; Fang, F.; Li, K.; Liu, L.; Chen, Y.; Guo, J. Effect of increase in salinity on ANAMMOX-UASB reactor stability. Environ. Technol. 2017, 38, 1184-1190. [CrossRef]

173. Meng, Y.; Yin, C.; Zhou, Z.; Meng, F. Increased salinity triggers significant changes in the functional proteins of ANAMMOX bacteria within a biofilm community. Chemosphere 2018, 207, 655-664. [CrossRef] [PubMed]

(C) 2019 by the authors. Licensee MDPI, Basel, Switzerland. This article is an open access article distributed under the terms and conditions of the Creative Commons Attribution (CC BY) license (http://creativecommons.org/licenses/by/4.0/). 